Francisco Salvio Cavalcante Pinto

\title{
Correlação clínico-patológica da expressão protéica do complexo CD44/ERM (Ezrin/Radixin/Moesin) no carcinoma da próstata
}

Tese apresentada à Faculdade de Medicina da Universidade de São Paulo para obtenção do Título de Doutor em Ciências.

Área de concentração: Oncologia

Orientador: Prof. Dr. Fernando Augusto Soares

São Paulo

2009 
Dados Internacionais de Catalogação na Publicação (CIP)

Preparada pela Biblioteca da

Faculdade de Medicina da Universidade de São Paulo

Creprodução autorizada pelo autor

Pinto, Francisco Salvio Cavalcante

Correlação clínico-patológica da expressão protéica do complexo CD44/ERM (Ezrin/Radixin/Moesin) no carcinoma da próstata /

Francisco Salvio Cavalcante Pinto. -- São Paulo, 2009.

Tese(doutorado)--Faculdade de Medicina da Universidade de São Paulo.

Departamento de Radiologia.

Área de concentração: Oncologia.

Orientador: Fernando Augusto Soares.

Descritores: 1.Neoplasias da próstata 2.Prostatectomia 3.Imonoistoquímica 4.Prognóstico 5.Sobrevida 


\section{A meus pais:}

Plinio Ramos Pinto e Laurelice Cavalcante Pinto, pelo apoio e amor incondicional, pois eles são exemplos de caráter, amor e honestidade, são pilares basilares na minha vida.

Meus irmãos:

Angélica

Manoel

Hortência

Orquídea

Pelo incentivo e confiança.

\section{À Leyla,}

Amiga e incentivadora constante.

Aos queridos filhos:

Plínio

Pedro Jorge

Salvio Filho

Pela vivência que me deram de experimentar o amor incondicional. 


\section{AGRADECIMENTOS}

Ao meu orientador, Prof. Dr. Fernando Augusto Soares, a quem tenho profundo respeito e admiração pelo profissional e pessoa que representa, e a quem agradeço o apoio e aprendizado que me proporcionou no seu laboratório.

Aos Profs. Drs. Dalgimar Beserra de Menezes e Régia Maria Vidal Patrocínio por ter aberto seu laboratório Biopse e o Serviço de Patologia do Hospital Geral de Fortaleza e ajudado na escolha dos blocos para estudo.

Ao Prof. Dr. José Wellingthon Lima, pela realização da análise estatística empregada nesta tese.

Ao amigo Dr. Mardhen Bezerra Araújo pelo auxílio e sugestões na elaboração desta tese, agradeço a amizade e o apoio, sempre presentes na elaboração deste trabalho.

Aos Drs. Cássio Santos Cortez, Marcelo Leite Costa e Carlos Antônio Bruno, pelas suas contribuições para discussões e confecção deste trabalho.

Ao Dr. Irismar de Azevedo Andrade, Residente do Hospital Geral de Fortaleza, pela ajuda na coleta de dados e dos blocos para estudo. 
Ao Serviço de Anatomia Patológica do Hospital A. C. Camargo e aos Drs. Isabela Werneck pela revisão das lâminas, Sueli Nonogaki pela realização das imunuistoquímicas e Carlos Ferreira pela construção do TMA.

A Sra. Suely Epifânio, bibliotecária do Hospital do Câncer pelo auxílio das citações bibliográficas.

Ao Dr. Stênio Zequi pela suas preciosas sugestões quando da aula de qualificação.

Aos colegas de cirurgia Dr. Mardhem Bezerra Araujo, Dr. Jerônimo Coelho e Dr. Julio Alexandre, pela amizade, incentivo e apoio.

A PRONUTRIR (Suporte Nutricional e Quimioterapia Ltda.) pelo apoio na realização deste trabalho.

A todos os que me ajudaram, e que comigo conviveram, e que porventura não tiveram seus nomes escritos nesta página, meu sincero agradecimento. 
Comete tudo que você possa fazer ou sonha poder. A ousadia tem dentro de si genialidade, poder e magia.

Goethe 
Esta Tese está de acordo com as seguintes normas, em vigor no momento desta publicação:

Referências: adaptado de International Committee of Medical Journals Editors (Vancouver)

Universidade de São Paulo. Faculdade de Medicina. Serviço de Biblioteca e Documentação. Guia de apresentação de dissertações, teses e monografias.

Elaborado por Anneliese Carneiro da Cunha, Maria Julia de A. L. Freddi, Maria F. Crestana, Marinalva de Souza Aragão, Suely Campos Cardoso, Valéria Vilhena, 2. ed. São Paulo: Serviço de Biblioteca e Documentação, 2005.

Abreviaturas dos títulos dos periódicos de acordo com List of Journals Indexed in Index Medicus. 


\section{SUMÁRIO}

Lista de Abreviaturas

Lista de Siglas

Lista de Figuras

Lista de Tabelas

Lista de Gráficos

Resumo

Summary

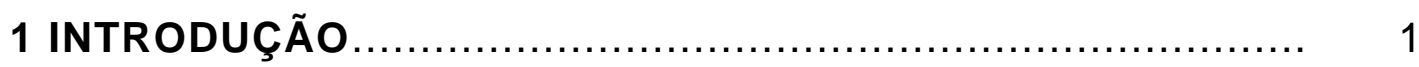

1.1 Câncer de próstata........................................... 4

1.2 Adesão celular (aspectos biomoleculares) $\ldots \ldots \ldots \ldots \ldots \ldots \ldots \ldots \ldots$

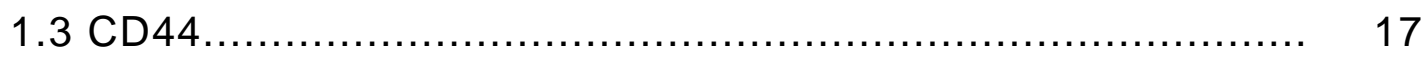

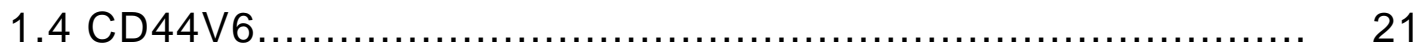

1.5 Família ERM - Ezrin, Radixin e Moesin....................... 22

1.6 Arranjo em matriz de amostras teciduais (tissue microarray

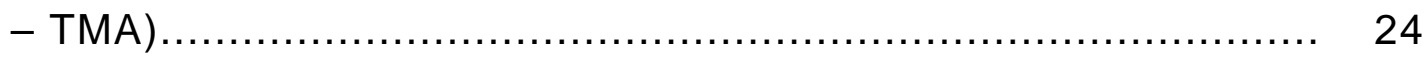

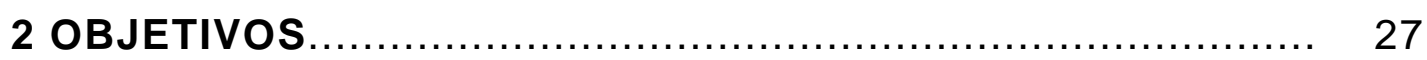

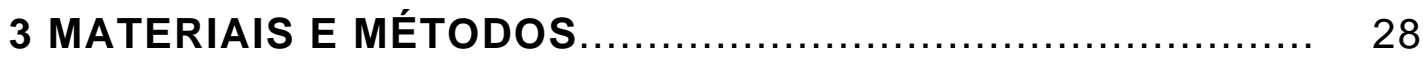

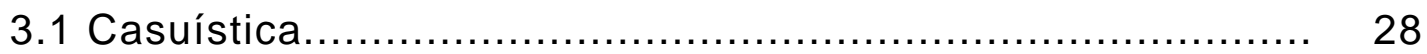

3.1.1 Amostra da pesquisa................................... 28

3.1.2 Critério de inclusão.................................... 29 
3.1.3 Critérios de exclusão.................................... 29

3.1.4 Dados de prontuários dos pacientes..................... 30

3.1.5 Grau de vulnerabilidade dos sujeitos e medidas protetoras propostas.......................................... 30

3.1.6 Avaliação do binômio risco-benefício ........................ 31

3.1.6.1 Riscos................................................... 31

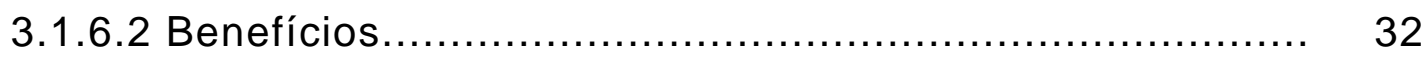

3.1.7 Análise estatística...................................... 32

3.2 Confecção das lâminas e do arranjo tecidual em matirz...... 33

3.2.1 Técnica de preparo do arranjo tecido em matriz (Tissue

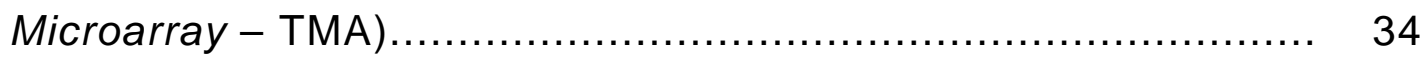

3.2.2 Técnica de preparo imunohistoquímico................... 38

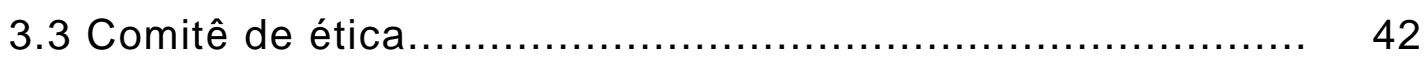

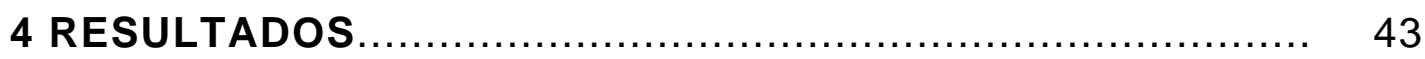

4.1 Análise descritiva............................................. 43

4.2 Sobrevida global........................................... 45

4.3 Relação da expressão imunoistoquímica dos marcadores CD44V6 e família ERM no adenocarcinoma acinar usual da

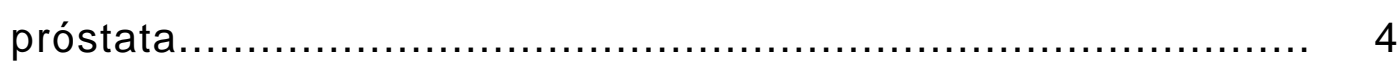

4.3.1 Expressão global dos marcadores........................ 47

4.3.2 Expressão dos marcadores em relação à idade.............. 49

4.3.3 Expressão dos marcadores em relação ao nível sérico de PSA 
4.3.4 Expressão dos marcadores em relação ao escore de Gleason.

4.3.5 Expressão dos marcadores em relação ao estadiamento clínico

4.3.6 Expressão dos marcadores em relação ao estadiamento clínico

4.3.7 Expressão dos marcadores em relação ao estadiamento anatomopatológico

4.3.8 Expressão dos marcadores em relação às biópsias positivas

4.3.9 Expressão dos marcadores em relação à recidiva laboratorial.

62

4.3.10 Expressão dos marcadores em relação à recidiva clínica 64

4.3.11 Expressão dos marcadores em relação à recidiva global.

4.3.12 Expressão dos marcadores em relação à ocorrência de óbito.

4.4 Expressão dos marcadores e sobrevida livre de doença.......

4.5 Análise multivariada dos fatores prognóstico clínicos e moleculares do adenocarcinoma usual de próstata

5 DISCUSSÃO.

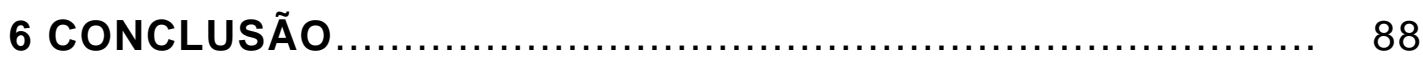

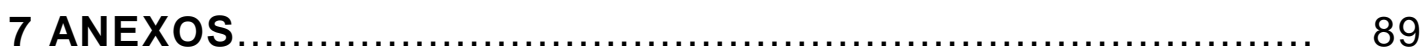

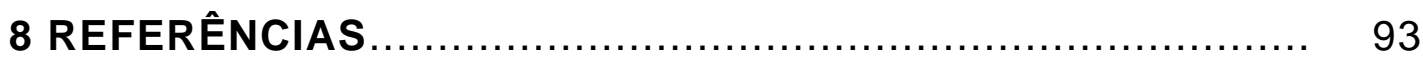




\section{LISTA DE ABREVIATURAS}

BTRUS - Biópsia Transretal da Próstata Guiada Pelo Ultrasom

CAP - $\quad$ Câncer da Próstata

CE - Ceará

DAB - Diaminobenzidina

DPSA - Densidade do Antígeno Prostático Específico

ECM - Matriz Extracelular

ECMR - Extracellular Matrix Receptor

EDTA - Ácido Etilenodiaminotetracético

ERM - Ezrin-Radixin-Moesin

et al. - E outros

HBP - Hiperplasia Benigna da Próstata

HGF - Hepatocyte Growth Factor

HCAN - Hyaluronate Receptors

HE - Hematoxilina e Eosina

IHQ - Imunohistoquímica

MEC - $\quad$ Membrana Extra Celular

PBS - Phosphate Buffered Saline

PCR - Polimerase Chain Reaction

PGP - Phagocytic Glycoprotein

PSA - Antígeno Prostático Específico

PSAL - $\quad$ Antígeno Prostático Específico Livre

PSAT - Antígeno Prostático Específico Total 


$\begin{array}{ll}\text { RNA - } & \text { Ácido Ribonucléico } \\ \text { TMA - } & \text { Tissue Microarray } \\ \text { TNM - } & \text { Tumor-Nodes-Metastasis } \\ \text { TR - } & \text { Toque Retal } \\ \text { VOL. - } & \text { Volume }\end{array}$




\section{LISTA DE SIGLAS}
AJCC - $\quad$ América Joint Comitee for Câncer Stagig
EUA - $\quad$ Estados Unidos da América
HCFMUSP - Hospital das Clínicas da Faculdade de Medicina da Universidade de São Paulo
INCA - Instituto Nacional do Câncer
OMS - $\quad$ Organização Mundial da Saúde 


\section{LISTA DE SÍMBOLOS}

$\begin{array}{ll}\%- & \text { porcentagem } \\ <- & \text { menor que } \\ >- & \text { maior que } \\ \mathrm{mg} \mathrm{-} & \text { miligrama } \\ \mathrm{mm}- & \text { milímetro } \\ \mathrm{mm}{ }^{2}- & \text { milímetro quadrado } \\ \mathrm{ng} / \mathrm{ml}- & \text { nanograma/mililitro } \\ \mathrm{pH} \mathrm{-} & \text { potencial hidrogeniônico }\end{array}$




\section{LISTA DE FIGURAS}

Figura 1 - Representação esquemática do processo de elaboração do Tissue Microarray (TMA)............... 37

Figura 2 - Representação esquemática dos blocos de TMA... 39 


\section{LISTA DE TABELAS}

Tabela 1 - Variáveis consideradas para análise neste estudo Distribuição dos casos de acordo com o estadiamento.

Tabela 2 - Distribuição dos casos de acordo com 0 estadiamento.

Tabela 3 - Distribuição dos casos de acordo com 0 estadiamento anatomopatológico.

Tabela 4 - Situação clínica dos 86 pacientes portadores de câncer de próstata submetidos à prostatectomia radical com linfadenectomia pélvica ao final da atualização dos dados

Tabela 5 - Prevalência de marcadores imunoistoquímicos na amostra de pacientes com adenocarcinoma acinar usual da próstata

Tabela 6 - Presença de marcadores imunoistoquímicos, segundo a idade, na amostra de pacientes com adenocarcinoma acinar usual da próstata

Tabela 7 - Relação entre a dosagem do PSA pré-operatório e a presença de marcadores imunoistoquímicos, na amostra de pacientes com adenocarcinoma acinar usual da próstata 
Tabela 8 - Relação entre o escore de Gleason e a presença de marcadores imunoistoquímicos, na amostra de pacientes com adenocarcinoma acinar usual da próstata............................................

Tabela 9 - Relação entre o estádio clínico do tumor e a presença de marcadores imunoistoquímicos, na amostra de pacientes com adenocarcinoma acinar usual da próstata

Tabela 10 - Relação entre o estádio patológico do tumor e a presença de marcadores imunoistoquímicos, na amostra de pacientes com adenocarcinoma acinar usual da próstata

Tabela 11 - Proporção de amostras de biópsias positivas, segundo a presença de marcadores imunoistoquímicos, numa amostra de pacientes com adenocarcinoma acinar usual da próstata.....

Tabela 12 - Ocorrência de recidiva laboratorial (VCDL ou MCDL) nos casos com adenocarcinoma acinar usual da próstata, segundo a presença dos marcadores imunoistoquímicos

Tabela 13 - Ocorrência de recidiva clínica (VCD ou MCD) entre pacientes com adenocarcinoma acinar usual da próstata, segundo a presença de marcadores imunoistoquímicos 
Tabela 14 - Ocorrência de recidiva global (VCD ou MCD ou VCDL ou MCDL) entre pacientes com adenocarcinoma acinar usual da próstata, segundo a presença de marcadores imunoistoquímicos.

Tabela 15 - Ocorrência de óbito, entre os pacientes com adenocarcinoma acinar usual da próstata, segundo a presença de marcadores imunoistoquímicos

Tabela 16 - Relação entre fatores prognóstico clínico e molécula Ezrin e a ocorrência de sobrevida livre de doença no adenocarcinoma acinar usual da próstata, ajustada e não ajustada para potenciais confundidores 


\section{LISTA DE GRÁFICOS}

Gráfico 1 - Curva atuarial de sobrevida global para 86 pacientes portadores de câncer de próstata submetidos à prostatectomia radical com linfadenectomia pélvica.............................. 46

Gráfico 2 - Ocorrência de sobrevida livre de doença, segundo a presença de Ezrin

Gráfico 3 - Ocorrência de sobrevida livre de doença, segundo a presença de Radixin $(0,412)$

Gráfico 4 - Ocorrência de sobrevida livre de doença segundo a presença de Moesin

Gráfico 5 - Ocorrência de sobrevida livre de doença segundo a presença de CD44V6. 
PINTO, F.S.C. Correlação clínico-patológica da expressão protéica do complexo CD44/ERM (Ezrin/Radixin/Moesin) no carcinoma da próstata. Tese (Doutorado). São Paulo: Faculdade de Medicina, Universidade de São Paulo, 2009.

\section{RESUMO}

Introdução: A prostatectomia radical é uma forma definitiva de tratamento do câncer localizado da próstata. Aproximadamente $40 \%$ dos pacientes tratados pela prostatectomia radical apresentaram progressão da doença, mesmo com a doença confinada ao órgão. Acurácia previsão do risco de recorrência é útil para se considerar uma terapia adjuvante ou alguma forma de tratamento investigacional. Observa-se, atualmente, que fatores anatomopatológicos e clínicos são insuficientes para o estadiamento preciso do câncer da próstata. Alguns estudos têm ressaltado a influência dos processos de adesão celular como pré-requisitos para invasão tumoral e metástase, sendo as moléculas CD44 e a família Ezrin-Radixin-Moesin (ERM), citadas como facilitadoras destes processos. Objetivos: Avaliar a expressão do complexo protéico CD44/ERM, no câncer da próstata, bem como sua associação com os fatores prognósticos e sobrevida nesta neoplasia. Material e Métodos: Foram analisados retrospectivamente os blocos de parafina de 100 pacientes, portadores de câncer localizado da próstata comprovado por biópsia transretal da próstata, submetidos à prostatectomia radical, no período de 1995 a 2000, do Departamento de Anatomia Patológica do Hospital Geral de Fortaleza e Laboratório Biopse. As lâminas de todos os casos selecionados para este estudo foram coradas com hematoxilina e eosina e revisadas. A preparação das lâminas foi feita pela técnica de "Tissue Microarray". A análise imunohistoquímica foi realizada, utilizado-se para controle positivo um tecido sabidamente com expressão da proteína a ser pesquisada. Foram realizadas duas lâminas de controle negativo. A primeira delas foi feita com a retirada do anticorpo primário e substituição por soro bovino fetal. O segundo controle negativo foi realizado com a retirada da reação do anticorpo secundário e substituição por soro contendo imunoglobulina do mesmo idiotipo do anticorpo primário, mas da mesma espécie. Os dados obtidos foram avaliados através do Teste do Qui-quadrado ou do Teste Exato de Fisher. Foram elaboradas curvas de sobrevivências, segundo o método de KaplanMeier. Curvas de sobrevivência foram comparadas através do Teste Log-Rank. Resultados: Os níveis de expressão imunohistoquímica de Ezrin,Radixin, Moezin e CD44V6 no câncer da próstata, foram respectivamente $48,8 \%, 16,3 \%, 20,9 \%$ e $70,9 \%$. Houve uma diminuição da expressão do Radixin e Moesin quando comparados com os valores de PSA pré-operatório. Esta diminuição da expressão foi estatisticamente significante $(p<0,008$ e $p<0,044)$ para os 
pacientes portadores de PSA $10 \mathrm{ng} / \mathrm{ml}$ no pré-operatório. A expressão do Ezrin teve significância estatística com relação à redução global da sobrevida dos pacientes quando comparado com as outras proteínas de adesão. Conclusão: A expressão da proteína Ezrin no câncer da próstata parece ser fator prognóstico independente na redução da sobrevida global, podendo vir a ser um importante marcador molecular em câncer da próstata.

Descritores: 1. Neoplasias da próstata. 2. Prostatectomia. 3. Imunoistoquímica. 4. Prognóstico. 5. Sobrevida. 
PINTO, F.S.C. Clinicopathologic correlation of the protein expression of CD44/ERM (Ezrin/Radixin/Moesin) complex in prostate carcinoma. Thesis (Doctorate). São Paulo: School of Medicine, University of São Paulo. 2009.

\section{SUMMARY}

Introduction: Radical prostatectomy is one form of definite treatment of clinically localized prostate cancer. Approximately $40 \%$ of the patients treated by radical prostatectomy presented disease progression, even with the disease confined to the organ. Predictive accuracy of the risk of recurrence is useful to be considered as an adjuvant therapy or in some form of investigational treatment. To date, anatomopathological and clinical factors are observed as insufficient for the precise staging of prostate cancer. Some studies have emphasized the influence of cellular adhesion processes as a prerequisite for tumor invasion and metastasis, with the molecules CD44 and the ERM (Ezrin/Radixin/Moesin) family cited as facilitators of these processes. Objectives: To evaluate the expression of CD44/ERM complex protein in prostate cancer, as well as its association with prognostic and survival factors in this neoplasm. Material and Methods: Retrospectively analyzed were the paraffin blocks of 100 prostate cancer patients, proven by transrectal ultrasound-guided prostate biopsy, submitted to radical prostatectomy in the period from 1995 to 2000 at the Department of Pathological Anatomy of the General Hospital of Fortaleza and a private laboratory (Fortaleza, Brazil). The slides of all cases selected for this study were stained with hematoxylin and eosin and reviewed. The preparation of the slides was done by tissue microarray technique. Immunohistochemical analysis was carried out using a tissue known to have expression to the protein being studied as positive control. Two slides of negative control were prepared. The first slide was prepared with the omission of the primary antibody and substitution by fetal bovine serum. The second negative control was prepared with the omission of the secondary antibody response and substitution by serum containing immunoglobulin of the same idiotype of the primary antibody, but of the same species. The obtained data were evaluated through chi-square test or Fisher's exact test. Survival curves were prepared following the Kaplan-Meier method. Survival curves were compared by the log-rank test. Results: The immunohistochemical expression levels of Ezrin, Radixin, Moezin and CD44V6 in prostate cancer were respectively $48.8 \%, 16.3 \%, 20.9 \%$ and $70.9 \%$. There was a reduction of Radixin and Moesin expression when compared with preoperative PSA values. This reduction of expression was statistically significant $(p<0.008$ and $p<0.044)$ for the patients with preoperative PSA $>10 \mathrm{ng} / \mathrm{ml}$. Ezrin expression had statistical significance in relation to reduction of overall patient 
survival when compared with other adhesion proteins. Conclusion: Ezrin protein expression in prostate cancer seems to be an independent prognostic factor in the reduction of overall survival, being able to become an important molecular marker in prostate cancer.

Descriptos: 1. Neoplasm of the prostate. 2. Prostatectomy. 3. Immunohistochemical. 4. Prognostic. 5. Survival. 


\section{INTRODUÇÃO}

O adenocarcinoma de próstata representa $15,3 \%$ das neoplasias que acometem os indivíduos do sexo masculino. Estudos recentes demonstram que 186.320 novos casos de câncer de próstata foram diagnosticados, ocorrendo 28.660 óbitos pela doença nos Estados Unidos, em 2008 (Jemal et al., 2008). No Brasil, neste mesmo período, estimou-se que aproximadamente 49.530 novos casos fossem diagnosticados, correspondendo a $28 \%$ de todos os tumores malignos não cutâneos do homem (Brasil, 2008).

O câncer da próstata origina-se quase sempre nas porções mais periféricas e posteriores da glândula, e pode permanecer em estado latente ou progredir, envolvendo os tecidos adjacentes, principalmente vesículas seminais, colo vesical e linfáticos locais, sendo o toque retal associado ao Antígeno Prostático Específico (PSA) a melhor forma de diagnosticar este tumor. A disseminação linfática é responsável pelo acometimento precoce dos linfonodos obturadores e da cadeia ilíaca interna. O envolvimento venoso é responsável pelo aparecimento de metástases ósseas.

Observa-se, atualmente, que fatores anátomo-patológicos e clínicos são insuficientes para o estadiamento preciso do tumor. Dessa forma, estudo de fatores bio-moleculares possibilitaria ampliar as ferramentas disponíveis para uma melhor avaliação dos 
pacientes, permitindo assim, um planejamento terapêutico mais adequado, evitando morbidade de cirurgias desnecessárias.

A progressão e a disseminação do adenocarcinoma da próstata estão associadas a alterações celulares e genéticas. Estas alterações são caracterizadas, por diminuição da adesão das células malignas entre si, interação entre estas células e proteínas da membrana basal, produção de enzimas que dissolvem a matriz extracelular e aumento da motilidade celular, com disseminação e fixação do tumor em outros locais. Isto poderá, posteriormente, converter a neoplasia em doença refratária aos hormônios androgênicos, alterando o seu prognóstico (Sommerfeld et al., 1995).

Neste contexto, uma propriedade fundamental de muitas proteínas de membrana plasmática é a associação destas com o citoesqueleto, para determinação da forma da célula, adesão celular, motilidade e outros processos de membrana, incluindo a exocitose e endocitose.

Um exemplo típico de proteína de adesão celular que sofre mudanças estruturais e funcionais dramáticas durante a transformação maligna do tumor é a CD44. Esta é o produto de um único gene, localizado no braço curto do cromossomo 11 (Goodfellow et al., 1982). A CD44 representa uma família de glicoproteínas transmembranas, receptoras de hialuronato (ácido hialurônico), envolvida na interação célula-célula e célula-matriz extracelular (Rudzki; Jothy, 1997; Goodison et al., 1999). Pode 
também ser chamada de phagocytic glycoprotein (Pgp-1) (Zhou et al., 1989), hyaluronate receptors (HCAM) (Goldstein et al., 1989), hermes antigen (Jalkanen et al., 1986) e extracellular matrix receptor III (ECMR III) (Wayner et al., 1988).

O gene CD44 contém 20 éxons, onde 10 deles (V1-V10) são éxons variantes, que combinados de formas diferentes, inserem-se no domínio extracelular. Os outros 10 éxons restantes (S1-S10) representam a isoforma Standard (Goodfellow et al., 1982). Expresso naturalmente em células epiteliais de proliferação ou em linfócitos ativos, seu domínio citoplasmático comunica-se com o citoesqueleto através da ankirina e da família ERM (Rudzki; Jothy, 1997).

A família ERM corresponde a três proteínas encontradas de forma independente em vários tecidos e células: Ezrin, Radixin e Moesin, que atuam na ligação dos filamentos de actina à membrana plasmática. A Ezrin é uma constituinte das microvilosidades (Bretscher et al., 1983; Pakkanen et al., 1987). Radixin é uma proteína envolvida na modulação da actina na junção aderente célula-célula (Tsukita et al., 1989) e Moesin é um ligante da heparina (Lankes et al., 1988).

O complexo protéico Ezrin-Radixin-Moesin (ERM) são hábeis em prover ligação regulada entre proteínas de membrana e o citoesqueleto cortical, sem esquecer que elas também participam de vias de transdução de sinais. 
Harrison et al. (2002) e Martin et al. (2003), estudaram a expressão da interação CD44/Ezrin, membro da família de proteínas ERM, no câncer de próstata, e concluíram que tal complexo desempenha um papel importante no processo de interação tumorendotélio, migração celular, adesão celular, progressão tumoral e metástase.

Diante desses achados, o estudo da expressão do complexo CD44/ERM no câncer da próstata, pode ser bastante valioso na sua associação com o quadro clínico-patológico, bem como na obtenção de conhecimentos para o diagnóstico, prognóstico e tratamento desta neoplasia.

\subsection{Câncer da próstata}

O câncer da próstata (CAP) é uma das principais causas de morte no Brasil, nos Estados Unidos e Europa Ocidental, representando a segunda causa de óbito por câncer em homens, sendo superado apenas pelo câncer de pulmão (Nelson et al., 2003).

No Brasil, o Instituto Nacional do Câncer (INCA, 2008) estima a incidência de 49.500 casos novos em 2008, correspondendo a um risco estimado de 52,43/100.000 homens. Considerando as diferenças regionais do país, o CAP apresenta risco estimado de 
69/100.000 na Região Sul, 63/100.000 na Região Sudeste, 46/100.000 na Região Centro-Oeste, 34/100.000 na Região Nordeste e 20/100.000 na Região Norte.

A maior incidência do câncer da próstata é evidenciada em países escandinavos como Suécia, Noruega e Finlândia. É considerada intermediária no Brasil e nos Estados Unidos, e baixa em países do extremo oriente, como China, Índia e Japão, sendo 6 a 25 vezes menor (Gronberg et al., 2003). Estudos epidemiológicos mostraram que a doença é dez vezes mais comum em norteamericanos do que em japoneses que residem no Japão. A frequência, contudo, se iguala quando os japoneses passam a residir nos Estados Unidos, indicando que são fatores ambientais ou dietéticos, e não a hereditariedade, os responsáveis pelo fenômeno. Diferenças no consumo de gordura animal talvez expliquem estas variações geográficas, já que a ingestão de alimentos com alto teor de gordura é elevada na Escandinávia. Para confirmar esta suspeita, o grupo do doutor William Fair, de Nova York, realizou um experimento com camundongos portadores de câncer da próstata. Decorrido algum tempo, o volume do tumor foi três vezes maior nos animais que receberam dieta com $40 \%$ de gordura do que naqueles cujo teor de gordura era de 2,3\% (Kolonel et al.,1999). História familiar de pai e irmão com CAP antes dos 60 anos de idade é outro marcador importante, podendo aumentar o risco em 3 a 10 vezes em relação à população geral (Bratt, 2002). 
O CAP atinge principalmente os homens acima de 50 anos de idade. O aumento da sua incidência na população é também decorrente do aumento da expectativa de vida do brasileiro verificada ao longo deste século, cuja tendência é ultrapassar os 70 anos no ano de 2020 (INCA, 2005).

O consumo de frutas, vegetais ricos em carotenóides como tomates e cenouras, e leguminosas como feijão, ervilhas e soja; vitaminas do tipo $A, D$ e $E$, e minerais como o selênio diminuem o risco de desenvolvimento do CAP. Um alto consumo energético total e ingestão de grande quantidade de carne vermelha, gorduras e derivados do leite tem sido relacionado a aumento da probabilidade de desenvolvimento do CAP. As aminas heterocíclicas e os hidrocarbonetos policíclicos aromáticos, o fator de crescimento análogo da insulina (IGF-1), o consumo excessivo de álcool e o tabagismo também são tidos como responsáveis pelo aumento do risco.

Enquanto a incidência do CAP está ligada às características demográficas da população, a mortalidade alta é causada pelo retardo do diagnóstico, que favorece a ocorrência de tumores com alta capacidade biológica de invasão local e de disseminação para outros órgãos. Tais tumores são incuráveis em fase metastática (Stamey; Kalabin, 1989; Coldman et al., 2003).

O câncer da próstata é uma doença que pode ser detectada precocemente por meio de métodos diagnósticos de triagem, sendo 
que os exames preventivos são: toque retal (TR) e o Antígeno Prostático Específico (PSA) sérico, anuais a partir de 50 anos de idade. Estes exames diminuem a incidência da doença avançada com influência nas taxas de mortalidade, atualmente a maioria dos pacientes diagnosticados com CAP possui a doença confinada ao órgão.

O TR tem alta especificidade (94\%) e baixa sensibilidade (50\%), assim como baixo valor preditivo positivo (21\%-53\%) (Perrer et al., 1996; Greenlee et al., 2001; Grubb; Kibel, 2007).

A descoberta do Antígeno Prostático Específico (PSA) em 1979 por Wang et al. (1979) marcou o início de uma nova era no diagnóstico e tratamento dos pacientes com CAP. Os programas de detecção de CAP utilizando o PSA, levaram a um aumento significativo das taxas de diagnósticos desta patologia, entretanto sua baixa sensibilidade e especificidade tem sido um importante fator limitante do método (Catalona et al., 1994). Apesar de amplamente aceito como marcador do CAP, o PSA é específico do tecido prostático e não do CAP. Deste modo, seus níveis séricos também podem elevar-se em pacientes com hiperplasia benigna da próstata (HBP) ou prostatites (Schalken et al., 2005). Devido à baixa especificidade, quando uma biópsia prostática é realizada em pacientes com níveis de PSA entre 3,0 a $10 \mathrm{ng} / \mathrm{ml}$ são observadas taxas de resultados negativos de aproximadamente 70 a $80 \%$ (Djavan et al., 2000). 
No entanto, níveis mais baixos de PSA não excluem a presença de CAP. No estudo de Thompson et al. (2004), que avaliou 2.950 homens com níveis de PSA abaixo de $4,0 \mathrm{ng} / \mathrm{ml}$ e sem alteração no toque retal, que foram submetidos a biópsia prostática, foi demonstrado que $15 \%$ dos homens tinham CAP e destes $15 \%$ já apresentavam escore de Gleason de 7 ou maior.

Com o intuito de melhorar a sensibilidade e a especificidade do método, várias formas de utilização do PSA foram propostas, incluindo a estratificação do PSA pelas faixas etárias (Oesterling et al., 1993) a razão do PSA pelo volume da próstata (densidade do PSA) (Benson et al., 1992), a variação do PSA no tempo (velocidade do PSA) (Carter et al., 1992), a razão do PSA livre pelo PSA total (\%PSAL/PSAT) (Partin et al., 1996), e o tempo de duplicação do PSA (Schmid et al., 1995). Como os níveis de PSA tendem a aumentar com a idade, Oesterling et al. (1993) determinaram valores de referência de acordo com as faixas etárias. Eles estudaram prospectivamente 471 homens saudáveis, com idades entre 40 e 79 anos participantes de um estudo para avaliar a história natural da hiperplasia benigna da próstata (HPB). Desta forma, indivíduos com 40 a 49 anos, 50 a 59 anos, 60 a 69 anos e 70 a 79 anos deveriam apresentar valores de PSA até $2,5 \mathrm{ng} / \mathrm{ml}, 3,5 \mathrm{ng} / \mathrm{ml}, 4,5 \mathrm{ng} / \mathrm{ml}$ e 6,5 $\mathrm{ng} / \mathrm{ml}$ respectivamente. Baseado no fato de que os valores de PSA podem ser influenciados pelo volume da próstata, Benson et al. (1992) descreveram o conceito de densidade do PSA (DPSA) e 
avaliaram seu valor preditivo no diagnóstico do CAP. Através da análise de 61 pacientes (41 com CAP e 20 com HPB), demonstraram que a DPSA média foi de 0,581 e 0,044 para pacientes com CAP e HPB respectivamente. Entretanto, nenhum paciente com HPB apresentou DPSA maior que 0,117.

Carter et al. (1992) avaliaram prospectivamente a variação do PSA no tempo em pacientes com CAP, a velocidade do PSA geralmente é maior de 0,75 ng/ml/ano. Partin et al. (1996) avaliaram o valor diagnóstico da \%PSAL/PSAT em 217 pacientes com diagnósticos confirmado por biópsia (139 com CAP e 78 com HPB) e demonstraram uma relação significativa entre esta medida e a probabilidade de biópsia positiva, sendo que enquanto os pacientes com a relação menor ou igual a $10 \%$ apresentaram uma probabilidade de CAP de $63 \%$, os pacientes com uma relação maior ou igual a $26 \%$ apresentaram uma probabilidade de apenas $2 \%$.

Finalmente, Schmid et al. (1995) acompanhando a velocidade de duplicação do PSA em 43 pacientes com CAP que não receberam tratamento, determinaram que para tumores localizados, o tempo médio de duplicação é de quatro anos e que os pacientes com HPB aumentam o PSA 12 vezes menos que os pacientes com CAP. No entanto, além de mais trabalhosas e algumas vezes não disponíveis, nenhuma destas formas de avaliação do PSA demonstrou ser superior a medida do seu valor absoluto no diagnóstico do CAP. 
Apesar de toda atenção voltada para o PSA como teste de detecção do CAP, o método padrão ouro para o diagnóstico definitivo da doença é a biopsia trans-retal da próstata guiada por ultrassom biópsia transretal da próstata guiada pelo ultrassom (BTRUS). Entretanto, devido à baixa sensibilidade do ultrassom, os protocolos convencionais de biópsia têm demonstrado taxas elevadas de resultados falso-negativos. Recentemente, uma análise de 10.429 BTRUS realizadas entre 1993 e 2001 e resgatadas de dois grandes bancos de dados norte-americanos demonstrou que o risco cumulativo de CAP aumenta significativamente com as biópsias repetidas. Desta forma, as taxas de detecção de CAP foram de $34 \%$, $50 \%, 62 \%$ e $68 \%$ para os pacientes submetidos a uma, duas, três e quatro biopsias respectivamente (Welsh et al., 2007).

Durante a última década, vários métodos têm sido utilizados para melhorar a sensibilidade do ultrassom. Hass et al. (2007) investigaram o valor das biópsias estendidas (com maior número de fragmentos) para o diagnósticos do CAP em próstatas removidas de autópsias. Eles compararam biopsias com 6, 12 e 18 fragmentos, e definiram que as taxas de sensibilidade foram de $30 \%, 53 \%, 53 \%$ respectivamente. A acurácia do ultrassom trans-real com Doppler utilizando contraste foi testada em 230 homens submetidos a um programa de detecção de CAP. O câncer foi detectado em $30 \%$ dos homens e taxas similares foram observadas entre os pacientes submetidos à biopsia com e sem contraste (Frauscher et al., 2002). 
Finalmente, o valor da ressonância magnética com espectroscopia para o diagnóstico do CAP foi analisado prospectivamente em 24 pacientes consecutivos com uma ou mais biópsia prévia negativa realizada por PSA persistentemente elevado e/ou alteração no exame digital da próstata. O CAP foi diagnosticado em $29,2 \%$ dos casos e a sensibilidade, especificidade e acurácia do método foram de $71 \%, 82,4 \%$ e $75 \%$ respectivamente.

A graduação histológica de Gleason (Gleason et al., 1977 e 1993), revista por Epstein et al. (2006), é o fator prognóstico isolado mais poderoso e mais frequentemente utilizado para graduação do CAP, valorizando-se a heterogeneidade histológica do CAP, o padrão glandular e a relação entre as glândulas e o estroma prostático. Neste sistema, os tumores são classificados em cinco padrões de acordo com a arquitetura glandular. O diagnóstico final na Escala de Gleason é dado pela soma dos padrões primário (predominante) e secundário (áreas menos representativas), de forma que as neoplasias sejam classificadas em um escore variável de 2 a 10.

Associado ao grau de Gleason na definição do prognóstico está o estadiamento que é fundamental na escolha da terapia. 0 sistema Tumor-Nodes-Metastasis (TNM), foi adotado para CAP pela América Joint Comitee for Câncer Stagig (AJCC) em 1975, foi posteriormente modificado em 1992, 1997 e em 2002, e é o mais amplamente utilizado para o estadiamento da doença na atualidade 
(Carter et al., 1992; Partin et al., 1996) (Quadro 1). Este sistema baseia-se na extensão do tumor primário, na presença de comprometimento linfonodal e na existência ou não de metástases em órgãos à distância.

Quando utilizado isoladamente, o valor prognóstico de qualquer critério em predizer a extensão e a progressão tumoral é limitado.

Visando melhor acurácia na determinação do prognóstico no CAP, pode-se recorrer ao uso de nomogramas, onde são combinados todos os fatores prognósticos conhecidos no CAP. Um dos nomogramas mais empregados, e já validado internacionalmente é o de Kattan, que utiliza principalmente os níveis de PSA, o estadiamento clínico e o grau de diferenciação histológica de Gleason para predizer a chance de cura quando o CAP é tratado através de cirurgia, radioterapia externa ou branquiterapia (Kattan et al., 2003).

No entanto, existem muitos fatores de erro. Um deles se refere ao grau histológico de Gleason, que caracteristicamente apresenta acurácia insatisfatória quando se compara a biópsia da próstata e a peça cirúrgica. O erro é de aproximadamente $30 \%$, sendo o evento mais comum a sub-graduação (Hyoung et al., 2006).

Deste modo, pode-se estar considerando um tumor indolente, com escore de Gleason $=6$, um carcinoma maior ou igual a 7 . Este é 
um problema universal, mas que ainda representa uma grande fonte de erro. Nestes casos, a discrepância pode ser tão significativa que limita a definição do comportamento biológico do tumor e, consequentemente a melhor escolha terapêutica. Com o intuito de melhorar as taxas de diagnóstico e prognóstico do CAP, vários marcadores biológicos têm sido isolados e testados no tecido prostático (Parekh et al., 2007).

\subsection{Adesão celular (aspectos biomoleculares)}

A adesão entre as células epiteliais é um fenômeno fundamental para a manutenção da homeostasia dos tecidos. As funções da membrana extracelular (MEC), uma rede macromolecular de proteínas estruturais fibrilares embebidas em um gel de polissacarídeos, vão desde a modulação da morfologia celular e proliferação; atuando como um substrato no qual as células podem aderir; e até como um reservatório de fatores de crescimento. A MEC está conectada ao núcleo da célula através de uma rede de proteínas que inclui moléculas de adesão transmembrana e o citoesqueleto (Hirohashi, 1998).

A organização celular tecidual também pode ser feita através da adesão direta célula-célula (Alberts et al., 2002), como por 
exemplo, nos tecidos epiteliais. Se levarmos em consideração o tecido epitelial e o conjuntivo, teremos dois exemplos, onde a função da MEC e da adesão célula-célula são muito diferentes. $O$ tecido conjuntivo, do ponto de vista estrutural, é dividido em três componentes: células, fibras e substância fundamental. O principal constituinte deste tecido é a matriz extracelular (MEC). No tecido conjuntivo as células estão esparsas e distribuídas numa matriz rica em polímeros fibrosos e substância fundamental, que suportam a maior parte do estresse mecânico sofrido pelo tecido. Por substância fundamental entende-se um complexo viscoso e altamente hidrofílico de macromoléculas aniônicas (glicosaminoglicanos e proteoglicanos) e glicoproteínas multiadesivas (laminina, fibronectina) que se ligam a proteínas receptoras, presentes na superfície das células, bem como a outros componentes da matriz, fornecendo força tênsil e rigidez à matriz. A interação maior se faz entre a célula e componentes da MEC, e não entre célula-célula. A fibronectina e a laminina parecem participar de modo importante no desenvolvimento dos tecidos embrionários. Elas também aumentam a habilidade de células neoplásicas cancerosas em invadir outros tecidos. Já no tecido epitelial, as células apresentam uma intensa adesão mútua e, para separá-las, são necessárias forças mecânicas relativamente grandes. As células estão unidas em camadas, o epitélio, e a MEC é composta de uma fina camada denominada lâmina basal, localizada sob a camada celular. Portanto, o tecido é formado basicamente por 
células, que suportam a maior parte do estresse mecânico e a adesão (Alberts et al., 2002).

Como vimos, a adesão celular é importante tanto nos processos biológicos quanto nas condições patológicas, e participa ativamente na regulação da diferenciação, proliferação e apoptose celular, portanto podemos considerar além do efeito sinalizador, o morfogenético.

A metástase é um processo onde uma célula, ou um grupo de células, é capaz de deixar o tumor primário, alcançar os tecidos adjacentes, sobreviver em sítios secundários e proliferar no sítio metastático. Uma porcentagem das células tumorais circulantes da ordem de $0,01 \%$ dá origem a uma nova metástase, sinalizando que a metástase é um evento competitivo altamente seletivo, e que favorece a sobrevivência de uma subpopulação de células metastáticas pré-existentes no tumor primário (Cavallaro; Christofori, 2001).

As células metastatizantes necessitam primeiramente migrar do tumor primário e atravessar barreiras teciduais, o que pode ocorrer através da migração da célula pelo estroma intersticial, ou necessitar de penetração e proteólise de obstáculos teciduais. A segunda etapa deste processo se inicia após a sobrevivência das células na corrente sanguínea e adesão nos leitos capilares de órgãos à distância. Essa etapa inclui o extravasamento, no qual as células deixam o lúmen do vaso e atingem um novo ambiente, 
originando as micrometástases que progressivamente se tornarão tumores secundários.

Como mencionado anteriormente, a membrana basal e o estroma intersticial constituem a matriz extracelular, o principal tecido conectivo que separa compartimentos orgânicos. A perda da continuidade da membrana basal é um indicador de malignidade nos carcinomas (Bosch et al., 2002).

Os estudos moleculares nos permitem entender melhor esses eventos. A primeira ocorrência na ativação do sprouting das células tumorais é a alteração da interação adesiva com suas membranas basais e também das células que interagem com a membrana basal vascular ou linfática exposta.

A seguir observa-se a migração dessas células em resposta a fragmentos de proteínas da MEC ou citocinas. As formas de adesão célula-célula, célula-MEC e moléculas de adesão que possam estar relacionadas com o fenótipo tumoral e metastático podem ser de três tipos: junções aderentes, desmossomos e hemi-desmossomos (Cooper; Hausman, 2003). 


\subsection{CD44}

O CD44 é uma glicoproteína multiestrutural de superfície celular que está envolvida em diversas atividades, incluindo interação célula-celula, célula-matriz, migração celular, apresentação de fatores de crescimento, citocinas, e transmissão de sinal da superfície celular para o interior, levando a apoptose, sobrevivência celular ou proliferação.

O N-terminal da molécula de CD44 forma um domínio globular, ou três subdomínios globulares. A região conservada do $\mathrm{N}$ terminal do domínio extracelular, a região transmembrana e a cauda citoplasmática, apresentam pelo menos $85 \%$ de homologia entre as espécies (Fox et al., 1994).

A região da membrana proximal tem $35 \%$ de homologia e a região variável tem $65 \%$ de homologia. A isoforma CD44 pode ser gerada por splicing (um processo onde o ácido ribonucléico - RNA mensageiro é editado para a remoção das sequências não codificadoras) alternativo de 9 éxons, que são inseridos entre duas regiões constantes que consistem em 5 e 4 éxons nas extremidades da molécula (Alberts et al., 2002).

No entanto, o número de variantes identificadas até o momento é de aproximadamente uma dúzia, a maioria detectada em células epiteliais, ceratinócitos, leucócitos ativados e células tumorais. O 
splicing direto do éxon 5 ao 16 (pulando todos os éxons variantes), gera CD44 expresso em células mesenquimais e em células hematopoiéticas. Além do splicing alternativo, modificações póstranslacionais através da glicosilação e incorporação de glicosaminoglicanos modificam a proteína, permitindo grande variação na sua expressão e funções (Bosch et al., 2002).

O ácido hialurônico é o principal ligante do CD44, mas outros componentes da matriz extracelular (ECM) tais como colágeno, fibronectina, fibrinogênio, laminina, sulfato de condroitina, osteopontina, I-selectina, e-selectina também possuem essa propriedade. Esta variedade de ligantes se deve à sua variedade estrutural. Em alguns casos o CD44 só interage com o ligante a partir de um estímulo externo. Existem três estados de ativação da CD44 identificados em células normais:

- O CD44 ativo, que se liga ao ácido hialurônico;

- O CD44 induzido, que não se liga ao ácido hialurônico, ou se liga de forma fraca, desde que ativado por anticorpos monoclonais, citocinas, fatores de crescimento ou éster forbol;

- CD44 inativo, que não se liga ao ácido hialurônico, mesmo na presença de agentes indutores. O envolvimento do CD44 em atividades patológicas pode ser confirmado, não só pela presença de certas isoformas, mas também pela interação 
com ligantes específicos (Naor et al., 2003).

Hepatócitos, células acinares do pâncreas e células tubulares do rim e do pâncreas não expressam CD44 (Terpe et al., 1994; MACKAY et al., 1994), assim como epêndima, epitélio do plexo coróide, superfícies do epitélio do estômago e intestino, glândula adrenal, epitélio germinativo do ovário, células germinativas testicular, músculo estriado, células de Sertoli e astrócitos (Rudzki; Jothy, 1997).

Estudos in vitro indicaram que a modificação da expressão de CD44 resulta num ligante de receptor diferente, e isso influência a motilidade celular, as propriedades invasivas e 0 potencial metastático do tumor, já que se rompe a interação normal epitéliomesênquima, contribuindo, assim, para a desorganização estrutural e funcional presente no câncer (Rudzki; Jothy, 1997; Goodison et al., 1999).

Stamenkovic et al. (1989; 1991) mostraram em seus estudos, que os tecidos tumorais contêm um número não usual de CD44 em relação ao número presente no tecido normal correspondente. Isso comprova a idéia de que a expressão de várias isoformas de CD44 pode influenciar na tumorogênese e no processo metastático.

Muitas isoformas variantes, especialmente aquelas contendo sequências de V6-V10, são altamente expressas nas neoplasias humanas (Rudzki; Jothy, 1997). Isoformas contendo sequências da 
variante V1 não têm sido identificadas em tecidos humanos, provavelmente, por V1 possuir um stop códon (Screaton et al., 1993).

Diversos estudos demonstraram que em diferentes tipos de câncer mais de uma isoforma pode estar envolvida na progressão tumoral. Em linfomas observou-se alta expressão das isoformas contendo as variantes V3, V6 e V9 (Koopman et al., 1993; Terpe et al., 1994).

A variante V5 é encontrada com expressão elevada em melanomas, porém melanócitos não neoplásicos não apresentam isoformas variantes, apenas CD44 standard (Hofmann et al., 1991; Manten-Horst et al., 1995). A elevada expressão de V6 está frequentemente, associada a diversos achados clínicos e morfológicos, como, por exemplo, a metástase linfonodal (Rudzki; Jothy, 1997).

A análise imunohistoquímica em tecido colorretal usando-se anticorpos monoclonais reconheceram todas as variantes das isoformas de CD44, demonstrando que podem ser encontradas tanto em adenomas como em carcinomas (Kim et al., 1994). 


\subsection{CD44V6}

A molécula de CD44 pertence a uma família de moléculas de adesão celular encontrada amplamente em células normais e também em células tumorais malignas em tecidos epiteliais, mesoteliais e hematopoéticos. O gen único do CD44 possui 20 éxons, dos quais 10 são normalmente expressos para codificar a molécula de CD44H (Alberts et al., 2002).

Os 10 éxons adicionais (V1 a V10) são expressos somente por um splicing alternativo do RNA nuclear. A expressão das moléculas variantes de splice CD44V6 específicas de adesão celular tem sido associada com metástases e com um pior prognóstico em certos tumores malignos, como os de mama. Um modelo complexo de expressão da variante CD44V6 em diferentes tumores comparado com a expressão de CD44 nas células normais de origem destes tecidos tem sido descrito (Fox et al., 1994).

Níveis elevados de expressão foram observados em muitos dos éxons variantes em carcinomas mamários, com origem em epitélio ductal, os quais normalmente não expressam CD44. Ao contrário, o epitélio gastrointestinal normal e cânceres de cólon expressaram baixos níveis de muitas variantes testadas (Bertoni et al., 2002). 


\subsection{Família ERM - Ezrin, Radixin e Moesin}

A família ERM corresponde a três proteínas encontradas de forma independente em vários tecidos e células, Ezrin, Radixin e Moesin, localizadas logo abaixo da membrana plasmática, atuam na ligação dos filamentos de actina a esta membrana.

Uma função normal das estruturas do citoesqueleto de actina é a de enrijecer ou promover a mudança da forma da membrana plasmática. Em muitos casos, os arranjos do citoesqueleto têm a função adicional de auxiliar na conexão das estruturas internas das células ao seu microambiente, incluindo a conexão a outras células ou elementos da matriz extracelular. Os filamentos de actina são críticos para o estabelecimento dessas conexões.

O domínio c-terminal das proteínas ERM liga-se diretamente à lateral dos filamentos de actina, enquanto que o domínio n-terminal liga-se à face citoplasmática de várias glicoproteínas transmembranas, como é o caso da CD44, um dos componentes da matriz extracelular. A família ERM pode existir na forma ativa, estendida, que oligomeriza e liga a actina à CD44 e na forma inativa, dobrada. Acredita-se que tanto as proteínas ERM, tal como a CD44 e suas variantes, possam estar relacionadas ao processo patogênico que confere maior capacidade de invasão e migração, e com isso a habilidade metastática da célula neoplásica (Vaheri et al., 1997). 
Harrison et al. (2002) estudaram a expressão da interação CD44/Ezrin, membro da família de proteínas ERM, no câncer de próstata, e concluíram que tal complexo desempenha um papel importante no processo de migração celular e metástase, já que interagem com as células endoteliais nas áreas de contato entre o tumor e o endotélio. Enfatizando esse achado, Martin et al. (2003), em sua revisão, relataram que o complexo CD44/Ezrin tem propriedades que sugerem a sua importância no processo de interação tumor-endotélio, migração celular, adesão celular, progressão tumoral e metástase.

Não há muitos estudos sobre a expressão das proteínas da família ERM e o comportamento tumoral. Alguns estudos mostraram correlação entre o nível de expressão de Ezrin e a progressão tumoral (Khanna et al., 2004; IImonen et al., 2005), com doença metastática em tumores pediátricos (Yu et al., 2004). O comportamento mais agressivo associado à expressão de Ezrin foi demonstrado em osteossarcomas (Ferrari et al., 2008), câncer de mama (Li et al., 2008), carcinoma nasofaríngeo (Shen Chen; Chen, 2008), câncer de próstata (Musial et al., 2007) e câncer colorretal (Wang et al., 2009).

Entretanto, a literatura demonstra também a expressão de Ezrin mais frequente em tecidos normais do que seus correspondentes neoplásicos. Moilanen et al. (2003) relataram que o epitélio ovariano saudável apresentou alta imunoreatividade para 
Ezrin, mas expressão fraca ou negativa em carcinoma ovariano, e que esta expressão estava associada à baixa sobrevida, grau histológico do tumor e idade avançada do paciente.

Bal et al. (2007) observaram uma alta imunoreatividade em mucosa gástrica normal, mas no carcinoma difuso houve uma diminuição da expressão de Ezrin em comparação com a mucosa normal. Esta se mostrou uma correlação inversa com a presença de metástase linfonodal e invasão do espaço linfovascular em carcinoma gástrico. Assim, os membros da família ERM têm sido alvo não somente de estudos sobre a sua atuação nos filamentos de actina, mas também de estudos envolvendo adesão e crescimento celular (Tsukita et al., 1994).

\subsection{Arranjo em matriz de amostras teciduais (tissue microarray -} TMA)

O câncer é resultado de fenômenos gênicos e epigenéticos concomitantes e ininterruptos (Mohr et al., 2002; Hanahan; Weinberg, 2000). O estudo simultâneo de vários fatores teoricamente relacionados pode ser útil na compreensão dos fenômenos oncológicos. Deste modo, a técnica do Microarranjo Tecidual Tissue Microarray (TMA) é atraente, pois permite a realização de 
painéis com múltiplos marcadores sincronicamente e sob as mesmas condições operacionais. A partir daí, possibilita-se a análise de vários eventos concomitantes com mais rapidez, menor custo e maior uniformidade técnica que nos processos imunohistoquímicos (IHQ) habituais (Kononen et al., 1998; Rimm et al., 2001).

O TMA, descrito por Kononen et al. (1998), já foi utilizado em várias neoplasias sólidas com resultados aceitáveis. Através desta técnica, fragmentos microscópicos são obtidos dos blocos de parafina de cada caso (blocos doadores) e são transferidas para um único bloco receptor, que pode comportar até 1.000 amostras. Do bloco receptor procede-se a secção de múltiplas lâminas para estudo.

Pode-se realizar uma determinada reação de $\mathrm{IHQ}$ para centenas de casos com um único padrão de desparafinização, hidratação, recuperação de antígenos, incubação com anticorpos ou amplificação e reação com cromógenos, ressaltando-se a economia de materiais e reagentes. No TMA, utilizam-se poucos microlitros de anticorpos ou reagentes em cada experimento. Numa dosagem habitualmente empregada para um caso nas técnicas tradicionais, pode-se estudar toda uma casuística com o TMA (Kononen et al., 1998; Rimm et al., 2001).

Embora neste método, o reduzido tamanho da amostra possa sugerir um risco de uma subavaliação, quando comparados os volume teciduais obtidos com esta técnica $(0,6 \mathrm{~mm}$ em diâmetro; 
0,282 $\mathrm{mm}^{2} /$ amostra) vários artigos tem revelado valor prognóstico similar de estudos com o TMA em comparação às técnicas habituais (Camp et al., 2000; Mucci et al., 2000; Nocito et al., 2001; Jakobsson et al., 2004). A confecção de mais de uma lâmina receptora com os mesmos casos (Rimm et al., 2001) e com amostras em duplicata em cada bloco receptor, permite confecção de duas a quatro amostras de cada caso, que submetidas ao mesmo marcador, eliminam este risco hipotético.

À exceção das técnicas de Polimerase Chain Reaction (PCR), que permitem a síntese de DNA para as necessidades de pesquisa, tecidos arquivados em parafina constituem um material de uso limitado e finito.

Vantagem adicional TMA é a preservação de maior quantidade de material humano arquivado nos blocos em comparação aos métodos tradicionais (Rimm et al., 2001). Recentemente autores têm descrito a utilidade desta técnica nas pesquisas de câncer urológico (Merseburger et al., 2006; Shergill et al., 2006) . 


\section{OBJETIVOS}

Baseado no discorrido da introdução, o presente trabalho tem como objetivo avaliar como as proteínas CD44V6 e o complexo ERM pode influenciar no comportamento do adenocarcinoma acinar usual da próstata avaliando:

1. A frequência da expressão imunoistoquímica em uma amostra de casos submetidos a prostatectomia total em Fortaleza/CE utilizando-se a técnica de tissue microarray.

2. Avaliar a presença ou perda da expressão de CD44V6 e complexo ERM com as variáveis clínicas patológicas e prognósticas clássicas (nível de PSA, escore de Gleason e estadiamento) e no comportamento clínico (taxas de recidiva clínica/laboratorial sobrevida livre de doença e sobrevida global) no adenocarcinoma acinar usual da próstata. 


\section{MATERIAIS E MÉTODOS}

\subsection{Casuística}

\subsubsection{Amostra da pesquisa}

Foram analisados retrospectivamente os blocos de parafina de cem pacientes, portadores de câncer localizado na próstata, comprovado por biópsia trans-retal da próstata, submetidos à prostatectomia radical com linfadenectomia ilíaca bilateral, operados por um único cirurgião no período de 1995 a 2000. Foram estudados os respectivos materiais, devidamente arquivados no Departamento de Anatomia Patológica do Hospital Geral de Fortaleza e Laboratório Biópse e passíveis de confirmação diagnóstica, conforme os critérios de inclusão e exclusão descritos abaixo.

Os pacientes foram seguidos regularmente e todos os dados relacionados com diagnóstico, tratamento e seguimento foram armazenados nos seus respectivos prontuários. Recidiva laboratorial foi definida como sendo o aumento do PSA acima de $0,2 \mathrm{ng} / \mathrm{ml}$ em duas medidas consecutivas no intervalo de três meses. Recidiva clínica foi definida como sendo recorrência local comprovada por 
citologia ou biopsia ou presença de metástases à distância. Óbito por câncer de próstata consiste por óbito devido a efeitos direto do tumor, metástases, ou do tratamento.

\subsubsection{Critérios de inclusão}

Foram incluídos neste estudo os blocos de parafina de pacientes portadores de adenocarcinoma acinar usual de próstata, submetidos a tratamento cirúrgico do tumor primário e a linfadenectomia regional, que possuíam material arquivado suficiente para novos coortes histológicos e confirmação do diagnóstico de câncer da próstata.

Foram considerados aptos ao estudo, os pacientes com seguimento atualizado.

\subsubsection{Critérios de exclusão}

Os casos que não se mostraram reagentes à imunohistoquímica foram excluídos deste estudo, bem como os pacientes que não possuíam seguimento adequado ou que tinham 
diagnóstico de um segundo tumor de qualquer linhagem neoplásica.

\subsubsection{Dados de prontuário dos pacientes}

Os prontuários das pacientes foram cadastrados e revisados sendo anotadas as informações referentes a idade, PSA iniciais précirurgia, estadiamento tumoral, escore de Gleason da biópsia, anatomopatológico da peça cirúrgica e seguimento. Em seguida, essas informações e os resultados da interpretação da imunoexpressão dos marcadores foram distribuídas em uma tabela do programa Microsoft Office Exce/ß 2003.

\subsubsection{Grau de vulnerabilidade dos sujeitos e medidas protetoras} propostas

Possivelmente, os sujeitos participantes deste estudo não sejam os mais representativos do universo pesquisado, mas esse é um risco de todo e qualquer processo de investigação. Para trabalhos futuros, o universo de pesquisa poderá ser ampliado, com o objetivo de minimizar este tipo de problema. 
O pesquisador assume o compromisso ético, de que os dados obtidos nesta pesquisa foram utilizados única e exclusivamente para estes fins. A identidade dos sujeitos pesquisados foi preservada e, consequentemente, foram omitidos quaisquer dados que possam relevar a identidade do paciente.

\subsubsection{Avaliação do binômio risco-benefício}

3.1.6.1 Riscos

A presente pesquisa não apresenta riscos ao sujeito pesquisado, pois consiste apenas na análise de dados arquivados em parafina, no Departamento de Anatomia Patológica do Hospital Geral de Fortaleza e Laboratório Biopse, e passíveis de confirmação diagnóstica.

Portanto, nenhum sujeito participante da pesquisa foi ou será exposto a qualquer teste físico ou psicológico. Além disso, o pesquisador garante o sigilo em relação à identidade dos sujeitos pesquisados. 


\subsubsection{Benefícios}

A conclusão desta pesquisa permitirá traçar o perfil de pacientes portadores de câncer de próstata em relação à idade; PSA iniciais pré-cirurgia; estadiamento tumoral; biopsia de Gleason; peça operatória; num seguimento de 8 anos.

Com os dados obtidos neste estudo, poderão ser analisadas as expressões imunohistoquímicas do complexo protéico CD44-ERM no carcinoma da próstata tratado pela prostatectomia radical.

Poderá ser avaliado o impacto dos níveis de expressão CD44ERM e suas correlações com os fatores que permitiram traçar o perfil de pacientes portadores de câncer de próstata no universo estudado, bem como, a avaliação do impacto da expressão CD44-ERM nas taxas de recidiva, recidiva laboratorial, recidiva clínica e óbito.

\subsubsection{Análise estatística}

Proporções foram comparadas através do Teste do Quiquadrado ou do Teste Exato de Fisher. Quando todos os valores esperados das células eram iguais ou superiores a 5 foi usado o Teste do Qui-quadrado. Quando, o valor esperado de pelo menos 
uma célula era menor do que 5 foi usado o Teste Exato de Fisher.

Foram elaboradas curvas de sobrevivências, segundo o método de Kaplan-Meier. Curvas de sobrevivência foram comparadas através do Teste Log-Rank. Proporções e curvas de sobrevivências foram consideradas significativamente diferentes quando o valor-p foi menor que $5 \%$. Os cálculos estatísticos foram realizados através do Software STATA 10.

\subsection{Confecção das lâminas e do arranjo tecidual em matriz}

Para a construção de um bloco TMA, existem critérios a serem obedecidos até a análise das reações, como: a seleção dos casos dos blocos doadores, a escolha da matriz adequada, a seleção da área a ser representada, a construção do bloco receptor, a obtenção das lâminas e, por fim, a manutenção dessas para os estudos (ANDRADE et al., 2003).

As lâminas originais de todos os casos selecionados para este estudo foram coradas com hematoxilina e eosina (HE) e revisadas pelo Serviço de Anatomia Patológica do Hospital A. C. Camargo (Dra. Isabela Werneck da Cunha e Prof. Dr. Fernando Augusto Soares). 
$\mathrm{Na}$ referida revisão procedeu-se a reclassificação anatomopatológica das variáveis em estudo conforme os critérios previamente estabelecidos para este estudo.

\subsubsection{Técnica de preparo do arranjo tecido em matriz (Tissue Microarray - TMA)}

A escolha dos blocos doadores para um TMA deve preferencialmente atender aos objetivos de uma linha de pesquisa, e não de um projeto único. Deste modo, um bloco doador deve ser avaliado quanto à quantidade e qualidade de fixação do material por meio de sua comparação com a lâmina original arquivada. Além disso, a qualidade dos informes clínico-patológicos disponíveis no caso é um critério a ser considerado. Embora casos sem informes completos não precisem ser descartados, quando se selecionam casos com bons dados de prontuário clínico, coorte respectivos, e não apenas para análise de expressão protéica comparativa.

Para este estudo, primeiramente foram avaliados os prontuários dos pacientes portadores de câncer localizado da próstata que foram submetidos à prostatectomia radical com linfadenectomia ilíaca bilateral, no período de 1995 a 2000, conforme os critérios de inclusão e exclusão descritos neste estudo. 
Foram consideradas aptas para este estudo cem amostras de pacientes, portanto, cem casos e seus respectivos blocos de parafina doadores com amostras de adenocarcinomas usuais de próstata designados por seus números de registro de laudo anatomopatológico correspondentes. Estas amostras foram separadas para a construção de um bloco receptor.

A escolha da matriz de construção do bloco depende da relação entre o número e o diâmetro dos cilindros a serem inseridos. Neste estudo, cada lâmina foi marcada em sua área tumoral mais representativa com caneta identificando a área para a punção. Estes casos constituem os blocos doadores.

Para a construção do bloco de TMA ou bloco receptor, no presente estudo, foi empregado o "arrayer" - manual da Beecher Instruments (Silver Spring, MD, EUA). A punção dos blocos doadores foi realizada com agulha de $1 \mathrm{~mm}$ de diâmetro.

A agulha de $1 \mathrm{~mm}$ de diâmetro foi escolhida para este estudo por oferecer boa amostragem, facilidade da construção do bloco receptor e menor dano ao bloco doador.

Os cilindros obtidos foram separados por uma distância de 0,2 mm. Cada caso foi representado em duplicata, sendo as reações imunohistoquímicas realizadas em duas lâminas, permitindo que 4 cilindros de cada caso fossem observados. 
De acordo com a literatura científica, coortes histológicos novos obtidos de blocos doadores devem ser analisados para avaliar a exata representação do tecido/neoplasia residual no bloco doador e manutenção de um coorte histológico nos arquivos da pesquisa sem retirar a lâmina original do arquivo do serviço. Nessa nova lâmina seleciona-se a área a ser representada no TMA com a caneta permanente. Feito este processo, procedimento semelhante deve ser realizado no bloco de parafina, o que facilita o preparo e a velocidade da construção do TMA.

De acordo com a literatura, o grau de perda dos cilindros e as estruturas amostradas devem ser verificados em níveis intervalados com a coloração de hematoxilina e eosina (HE), conforme se procedeu neste estudo. Além disso, o bloco é útil enquanto as perdas das amostras forem menores que $20 \%$, e excelentes os coortes com $95 \%$ de aproveitamento.

Deste modo, no presente estudo, construiu-se um mapa, com identificação detalhada de cada cilindro, permitindo a localização exata de cada caso. Um caso foi definido como adequado, quando o coorte resultante ocupou pelo menos $24 \%$ da área total do cilindro. Foram realizados coortes sequenciais de quatro micrômetros de espessura, colhidos em lâminas adesivas oriundas da Instrumedics (Hacksensack NJ, EUA).

Para maximizar o uso do TMA, todos os coortes de cinco milímetros foram colhidos em uma única sessão e armazenados para 
uso posterior. Para tal, foram utilizadas lâminas adesivas da Instrumedics Inc (EUA). Tal lâmina contém um adesivo próprio e os coortes são colhidos em fita adesiva com a transferência posterior para a lâmina. Esta técnica permite que nenhum coorte seja perdido e o pesquisador tenha o exato controle da profundidade do cilindro de tecido.

Os coortes são colhidos em fita adesiva e aplicados nessas lâminas. Por último, a fita adesiva é retirada pela exposição à luz ultravioleta cedida pelo próprio fabricante. Como todas as lâminas são colhidas ao mesmo tempo, foi considerada como ponto importante a manutenção dos coortes no sentido de preservar reatividade antigênica.

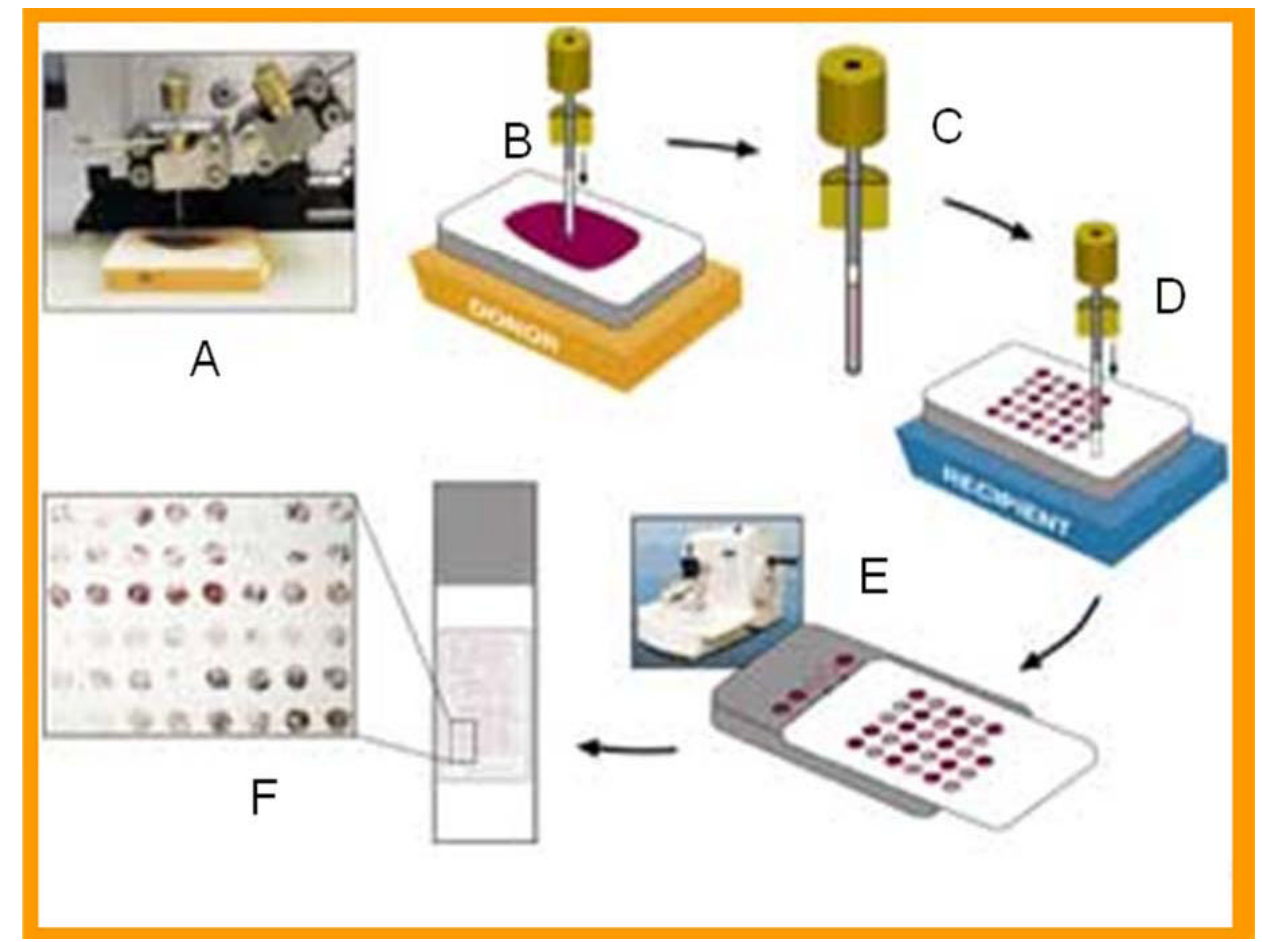

Figura 1 - Representação esquemática do processo de elaboração do Tissue Microarray (TMA). 
Fonte: Giltnane e Rimm (2004).

\section{Legenda:}

Em sentido horário, visualizamos:

A: Fotografia do aparelho.

B: Representa a agulha perfurando e retirando o cilindro de tecido do bloco doador (cor de vinho).

C: Representação da agulha com cilindro tecidual em seu interior.

D: Demonstra a inserção da agulha contendo o cilindro de tecidual que será introduzido num dos orifícios do bloco receptor (em branco), como se fosse "macho e fêmea".

E: Lâmina resultante da secção do bloco receptor pelo micrótomo (fotografado em no detalhe). A secção de cada cilindro origina um disco tecidual correspondente.

F: TMA pronto. O detalhe mostra imagem amplificada de uma região da lâmina, com várias amostras.

\subsubsection{Técnica de preparo imunohistoquímico}

As reações imunohistoquímicas para cada anticorpo foram realizadas em duas lâminas TMA. Como foi dito anteriormente, existem dois cilindros de cada tumor alocados no bloco de TMA, o que fez com que as análises fossem feitas em quadriplicada (vide figura a seguir). 


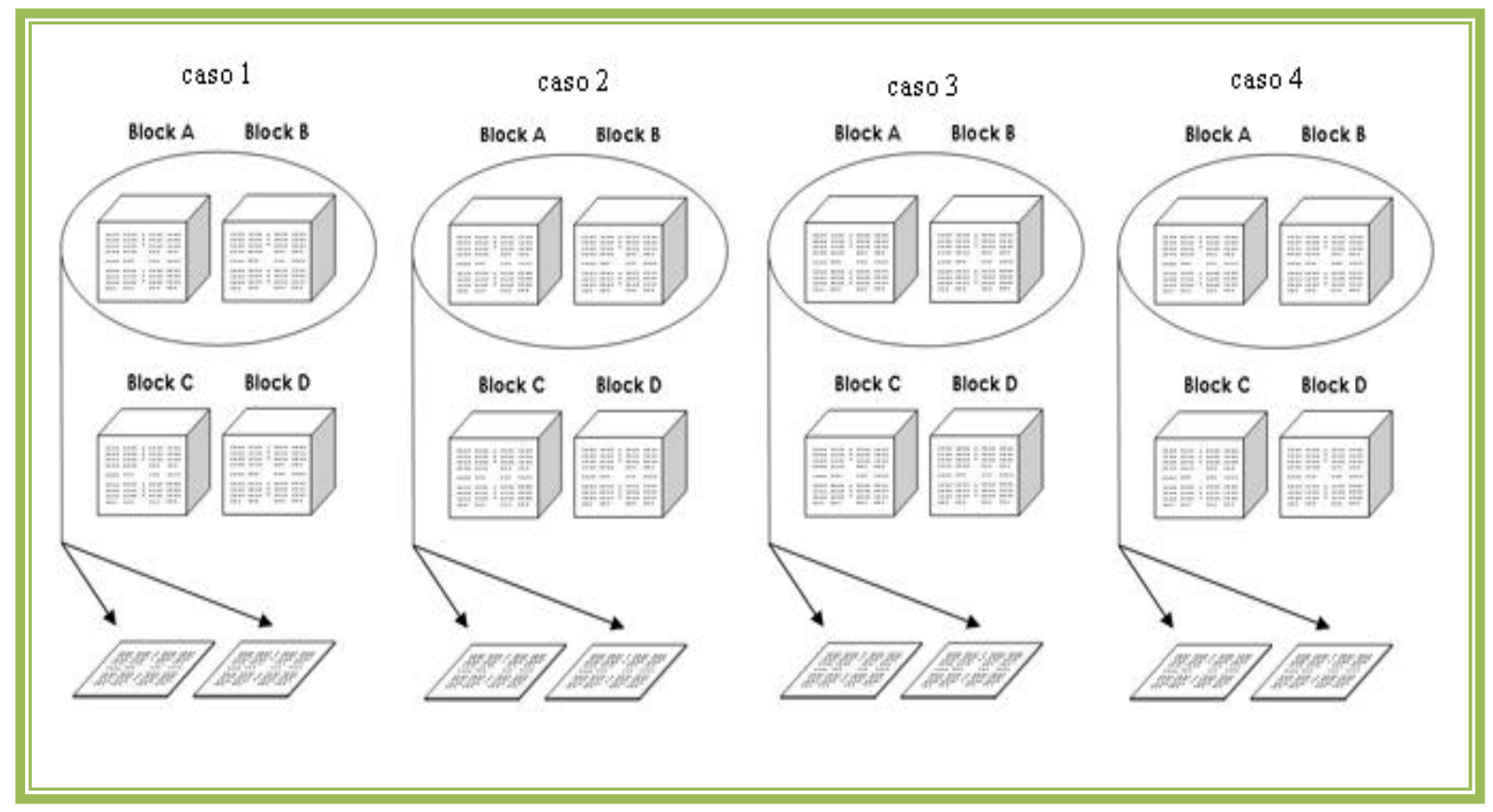

Figura 2 - Representação esquemática dos blocos de TMA.

Fonte: Elaborado pelo pesquisador.

De acordo com a figura supracitada, quatro núcleos são retirados de cada bloco doador. Um desses núcleos é inserido em cada array destinatário de quatro blocos para criar e replicar blocos receptores fixados para cada caso. Um mínimo de dois pontos, um de cada um dos dois do array replicado nos blocos, é fornecido.

De acordo com os critérios estabelecidos para este estudo, os coortes histológicos foram desparafinizados e preparados por 
passagens sucessivas por xilol e etanol e submetidos à recuperação antigênica pelo calor com irradiação em banho-maria, utilizando-se tampão EDTA + Triz, pH 9,0 por 40 minutos, deixando-se mais 10 minutos à temperatura ambiente.

Em seguida, foi realizado o bloqueio da peroxidade endógena com solução de peróxido de hidrogênio a 3\% (água oxigenada 10 vol.), com três trocas de 5 minutos cada. Após o bloqueio da peroxidase, também foi realizado o bloqueio de proteína (DAKO®) Protein Block Serum-Free) por 20 minutos. A seguir, as lâminas foram incubadas com os anticorpos primários, conforme o quadro 2 , por 2 horas, em câmara úmida, à temperatura ambiente.

\begin{tabular}{|c|c|c|c|c|}
\hline Anticorpo & Marca & Clone & Recuperação & Revelação \\
\hline CD44V6 & NovoCastra & VFF-7 & $\begin{array}{c}\text { Panela/CT, } \\
\mathrm{pH} 6.0\end{array}$ & $\begin{array}{c}\text { NovoLink } \\
\text { (NovoCastra) }\end{array}$ \\
\hline Ezrin & Neomarkers & $3 \mathrm{C} 12$ & $\begin{array}{c}\text { Panela/CT } \\
\mathrm{pH6.0}\end{array}$ & $\begin{array}{c}\text { NovoLink } \\
\text { (NovoCastra) }\end{array}$ \\
\hline Moesin & Neomarkers & $38 / 87$ & $\begin{array}{c}\text { Panela/CT } \\
\text { pH6.0 }\end{array}$ & $\begin{array}{c}\text { NovoLink } \\
\text { (NovoCastra) }\end{array}$ \\
\hline Radixin & Epitomics & EP1862Y & $\begin{array}{c}\text { Panela/CT } \\
\text { pH6.0 }\end{array}$ & $\begin{array}{c}\text { NovoLink } \\
\text { (NovoCastra) }\end{array}$ \\
\hline
\end{tabular}

Quadro 1 - Anticorpos empregados, com respectivos clones, títulos, nomes de fabricantes e códigos.

Fonte: Elaborado pelo pesquisador. 
Após incubação, as lâminas foram lavadas em tampão Phosphate Buffered Saline (PBS) com três trocas de 5 minutos cada, sendo incubadas, posteriormente, com NovoLink Max Polymer (NovoCastra), por 30 minutos, à temperatura ambiente, passando em seguida por três lavagens de 5 minutos em PBS. As lâminas foram reveladas com solução de Diaminobenzidina (DAB, DAKOß) e contra coradas com hematoxilina de Harris (Merck®). As reações foram realizadas em duas lâminas de TMA com intervalo de sessenta coortes entre elas, garantindo que as células analisadas não fossem as mesmas. Procedeu-se então a montagem das lâminas em Entellan (MERCK, Germany).

Para todos os anticorpos testados foram realizadas lâminas de controle da reação. Como controle positivo foi utilizado um tecido sabidamente com expressão da proteína a ser pesquisada. Foram realizadas duas lâminas de controle negativo. A primeira delas foi feita com a retirada do anticorpo primário e substituição por soro bovino fetal. O segundo controle negativo foi realizado com a retirada da reação do anticorpo secundário e substituição por soro contendo imunoglobulina do mesmo idiotipo do anticorpo primário, mas da mesma espécie.

Afins de avaliação e comparação com os dados clínicopatológicos e comportamento biológico, os casos foram classificados como presentes e ausentes. Foram considerados presentes aqueles 
casos cuja expressão do marcador pode ser identificado em pelo menos $10 \%$ das células tumorais indiscutivelmente, e sendo considerados ausentes aqueles casos que não preencheram estes critérios. A imunorreatividade do tecido foi testado pela expressão de citoceratina $A E 1 / A E 3$, conforme critério de inclusão.

\subsection{Comitê de ética}

Todas as amostras utilizadas neste estudo foram codificadas, garantindo sua confidencialidade. Este projeto foi submetido ao Comitê de Ética em Pesquisas do Hospital das Clínicas da Faculdade de Medicina da Universidade de São Paulo (HCFMUSP), tendo sido aprovado na reunião de 05/11/2008 (Protocolo n.o 0930/08). 


\section{RESULTADOS}

\subsection{Análise descritiva}

Foram examinados cem blocos de parafina de cem pacientes portadores de câncer da próstata submetidos a prostatectomia radical, quatorze blocos foram excluídos do estudo, oito por ausência de tumor suficiente para estudo e seis por ter soltado o coorte no preparo do TMA. A idade média dos pacientes era de $64 \pm 8,4$ anos (42-81 anos). O tempo médio de seguimento era de $8 \pm 2$ anos (5-14 anos).

Os pacientes foram distribuídos segundo o PSA pré-operatório com media de PSA $=11,8 \pm 8,5 \mathrm{ng} / \mathrm{ml}(1,56-48 \mathrm{ng} / \mathrm{ml})$. Quanto ao escore de Gleason dos pacientes apresentavam-se com média de $6,2 \pm 1,4(2-9)$

Tabela 1 - Variáveis consideradas para análise neste estudo. 


\begin{tabular}{l|r|r|r|r}
\hline \multicolumn{1}{c|}{ Variável } & $\begin{array}{c}\text { Valor } \\
\text { Mínimo }\end{array}$ & $\begin{array}{c}\text { Valor } \\
\text { Máximo }\end{array}$ & $\begin{array}{c}\text { Valor } \\
\text { Médio }\end{array}$ & $\begin{array}{c}\text { Desvio } \\
\text { Padrão }\end{array}$ \\
\hline Idade & 42 & 81 & 64 & 8,4 \\
Escore de Gleason & 2 & 9 & 6,2 & 1,4 \\
PSA pré-operatório & 1,56 & 48 & 11,8 & 8,5 \\
Sobrevida sem doença (anos) & 5 & 14 & 8 & 2 \\
\hline
\end{tabular}

Fonte: Elaborada pelo pesquisador.

\section{Estadiamento Clínico:}

Os pacientes estudados distribuíram-se de acordo com o estadiamento clínico: T1c $=32(35,96 \%), T 2 a=23(25,84 \%)$, T2b $=$ $20(22,47 \%), \mathrm{T} 2 \mathrm{c}=11(12,36 \%), \mathrm{T} 3 \mathrm{a}=2(2,25 \%)$ e T3b $=1(1,12 \%)$.

Tabela 2 - Distribuição dos casos de acordo com 0 estadiamento.

\begin{tabular}{ccc}
\hline Estádio Clínico & Casos & Valor Percentual \\
\hline T1c & 32 & $35,96 \%$ \\
T2a & 23 & $25,84 \%$ \\
T2b & 20 & $22,47 \%$ \\
T2c & 11 & $12,36 \%$ \\
T3a & 2 & $2,25 \%$ \\
T3b & 1 & $1,12 \%$ \\
T1 (total) & 32 & $35,96 \%$ \\
T2 (total) & 54 & $60,67 \%$ \\
T3 (total) & 3 & $3,37 \%$ \\
\hline
\end{tabular}


Fonte: Elaborada pelo pesquisador.

\section{Estadiamento Patológico:}

No estudo da peça operatória obtivemos o seguinte estadiamento patológico: $\mathrm{T} 2 \mathrm{a}=10(11,63 \%), \mathrm{T} 2 \mathrm{~b}=15(17,44 \%), \mathrm{T} 2 \mathrm{c}=37$ $(43,02 \%), \mathrm{T} 3 \mathrm{a}=9(10,47 \%), \mathrm{T} 3 \mathrm{~b}=10(11,63 \%), \mathrm{T} 3 \mathrm{c}=1(1,16 \%)$ e T4 $=$ $4(4,65 \%)$.

Tabela 3 - Distribuição dos casos de acordo com o estadiamento anatomopatológico.

\begin{tabular}{ccc}
\hline Estádio Anatomopatológico & Casos & Valor Percentual \\
\hline T2a & 10 & $11,63 \%$ \\
T2b & 15 & $17,44 \%$ \\
T2c & 37 & $43,02 \%$ \\
T3a & 10 & $11,63 \%$ \\
T3b & 10 & $11,63 \%$ \\
T4 & 04 & $4,65 \%$ \\
\hline
\end{tabular}

Fonte: Elaborada pelo pesquisador.

\subsection{Sobrevida global}

O período de seguimento variou de 0,1 a 14,0 anos, com média de 8,0 anos, com desvio padrão de 2 anos; ao final $52(60,4 \%)$ 
pacientes estavam vivos sem doença, 23 (26,7\%) apresentavam recidiva laboratorial, $5(5,9 \%)$ estavam com recidiva clínica, e 6 $(7,0 \%)$ morreram da doença (Tabela 4$)$.

Tabela 4 - Situação clínica dos 86 pacientes portadores de câncer da próstata submetidos à prostatectomia radical com linfadenectomia pélvica ao final da atualização dos dados.

\begin{tabular}{ccc}
\hline Situação Clínica & Casos & Valor Porcentual \\
\hline Vivos sem doença & 52 & $60,4 \%$ \\
Recidiva Laboratorial & 23 & $26,7 \%$ \\
Recidiva Clínica & 5 & $5,9 \%$ \\
Óbitos pela doença & 6 & $7,0 \%$ \\
\hline
\end{tabular}

Fonte: Elaborada pelo pesquisador.

Seguimento (anos): média 8,0 \pm 2 anos; $(0,1$ a 14,0).

A curva de sobrevida global atuarial de 86 pacientes portadores de câncer da próstata submetidos à prostatectomia radical com linfadenectomia pélvica encontra-se gráfico 1 .

Sobrevivencia de uma amostra de portadores de cancer de prostata.

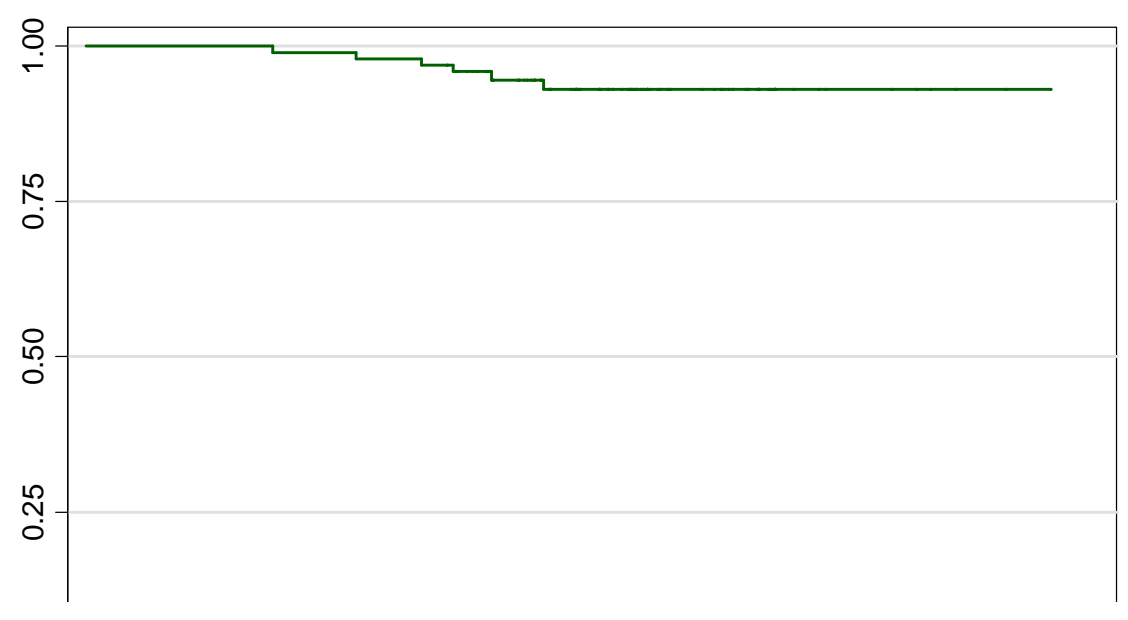


Gráfico 1 - Curva atuarial de sobrevida global para 86 pacientes portadores de câncer da próstata submetidos à prostatectomia radical com linfadenectomia pélvica.

4.3 Relação da expressão imunoistoquímica dos marcadores CD44V6 e família ERM no adenocarcinoma acinar usual da próstata

\subsubsection{Expressão global dos marcadores}

Todos os marcadores testados tiveram casos positivos (presente) como negativos permitindo as comparações com os parâmetros clínico-patológicos. O marcador Ezrin encontra-se em números semelhantes estando ausente em 44 casos $(51,2 \%)$ e presente em 42 casos (48,4\%). Quanto ao Radixin, este esteve ausente na maioria dos casos testados (83,7\%) e ausente em 14 casos $(16,3 \%)$. O terceiro membro da família ERM, o Moesin está ausente na maioria dos casos (68 casos, 79,1\%) e presente em 18 casos $(20,9 \%)$. 
Finalmente a expressão de CD44V6 está predominantemente presente ( 61 casos, $70,9 \%$ ) e ausente em 25 casos $(29,1 \%)$. Chama atenção a alta percentagem de ausência dos marcadores Radixin e Moesin e a presença do CD44V6. (Tabela 5).

Tabela 5 - Prevalência de marcadores imunoistoquímicos na amostra de pacientes com adenocarcinoma acinar usual de próstata.

\begin{tabular}{l|l|l}
\hline \multirow{2}{*}{ Marcadores } & \multicolumn{2}{|c}{ Frequência } \\
\cline { 2 - 3 } & N. & $\%$ \\
\hline
\end{tabular}

Ezrin:

-Ausente

44

51,2

-Presente

42

48,8

Radixin:

-Ausente

72

83,7

-Presente

14

16,3

Moesin:

-Ausente

68

79,1

-Presente

18

20,9 
CD44V6:

-Ausente

-Presente

Fonte: Elaborada pelo pesquisador.

\subsubsection{Expressão dos marcadores em relação à idade}

A expressão dos marcadores imunoistoquímicos não apresentou diferenças significativas quando comparados com relação à mediana da idade dos pacientes divididos em dois estratos distintos com coorte em 65 anos.

O Ezrin está ausente em $52,5 \%$ para pacientes com menos de 65 anos e 50,0\% para maiores de 65 anos; o Radixin está ausente em $87,5 \%$ para menores de 65 anos e $80,4 \%$ para acima de 65 anos e o Moesin não mostrou expressão em $80,0 \%$ para menores de 65 anos e 78,3\% para maiores de 65 anos. Ao contrário, a expressão do CD44V6 encontra-se presente em $70,0 \%$ e $71,7 \%$ dos casos respectivamente.

Estes resultados podem ser apreciados na Tabela 6 a seguir.. 
Tabela 6 - Presença de marcadores imunoistoquímicos, segundo a idade, na amostra de pacientes com adenocarcinoma acinar usual da próstata.

\begin{tabular}{c|c|c|c|c|c|c}
\hline \multirow{2}{*}{$\begin{array}{c}\text { Marcador } \\
\text { Bioquímico }\end{array}$} & \multirow{2}{*}{ Total } & \multicolumn{2}{|c|}{$42-65$ anos } & \multicolumn{2}{|c|}{$66-81$ anos } & \multirow{2}{*}{ Valor-p } \\
\cline { 3 - 5 } & & $\mathrm{N}$ & $\%$ & $\mathrm{~N}$ & $\%$ & \\
\hline
\end{tabular}

Ezrin:

$\begin{array}{lllllll}\text {-Ausente } & 44 & 21 & 52,5 & 23 & 50,0 & \\ \text {-Presente } & 42 & 19 & 47,5 & 23 & 50,0 & 0,817\end{array}$

Radixin:

$\begin{array}{lrrrrrr}\text {-Ausente } & 72 & 35 & 87,5 & 37 & 80,4 & \\ \text {-Presente } & 14 & 5 & 12,5 & 9 & 19,6 & 0,376\end{array}$

Moesin:

$\begin{array}{lrrrrrr}\text {-Ausente } & 68 & 32 & 80,0 & 36 & 78,3 & \\ \text {-Presente } & 18 & 8 & 20,0 & 10 & 21,7 & 0,843\end{array}$


CD44V6:

$\begin{array}{lllllll}\text {-Ausente } & 25 & 12 & 30,0 & 13 & 28,3 & \\ \text {-Presente } & 61 & 28 & 70,0 & 33 & 71,7 & 0,859\end{array}$

Fonte: Elaborada pelo pesquisador.

\subsubsection{Expressão dos marcadores em relação ao nível sérico de} PSA

$\mathrm{Na}$ tabela 7, identifica-se uma diferença estatisticamente significativa da diminuição da expressão do Radixin (97\%) e do Moesin (91\%) em relação aos pacientes com o valor do PSA préoperatório acima de $10 \mathrm{ng} / \mathrm{ml}$.

Por outro lado não houve diferenças para os marcadores Ezrin e CD44V6. O Ezrin encontra-se ausente em 46,9\% e 58,8\% nos casos de PSA abaixo e acima de $10 \mathrm{ng} / \mathrm{ml}$ respectivamente. Já o CD44V6 apresenta aumento da expressão com $75,5 \%$ e $61,8 \%$ nas amostras. 
Tabela 7 - Relação entre a dosagem do PSA pré-operatório e a presença de marcadores imunoistoquímicos, na amostra de pacientes com adenocarcinoma acinar usual da próstata.

\begin{tabular}{l|l|l|c|c|c|c}
\hline \multirow{2}{*}{$\begin{array}{l}\text { Marcador } \\
\text { Bioquímico }\end{array}$} & \multirow{2}{*}{ Total } & \multicolumn{2}{|l|}{ PSA $<10 \mathrm{ng} / \mathrm{mI}$} & \multicolumn{2}{|c|}{$\mathrm{PSA}>10 \mathrm{ng} / \mathrm{mI}$} & \multirow{2}{*}{ Valor-p } \\
\cline { 3 - 5 } & & $\mathrm{N}$ & $\%$ & $\mathrm{~N}$ & $\%$ & \\
\hline
\end{tabular}

Ezrin:

$\begin{array}{lllllll}\text {-Ausente } & 43 & 23 & 46,9 & 20 & 58,8 & \\ \text {-Presente } & 40 & 26 & 53,1 & 14 & 41,2 & 0,287\end{array}$

Radixin:

$\begin{array}{lrrrrrr}\text {-Ausente } & 70 & 37 & 75,5 & 33 & 97,1 & \\ \text {-Presente } & 13 & 12 & 24,5 & 1 & 2,9 & 0,008\end{array}$

Moesin:

$\begin{array}{lrrrrrr}\text {-Ausente } & 67 & 36 & 73,5 & 31 & 91,2 & \\ \text {-Presente } & 16 & 13 & 26,5 & 3 & 8,8 & 0,044\end{array}$


CD44V6:

$\begin{array}{lrrrrrr}\text {-Ausente } & 25 & 12 & 24,5 & 13 & 38,2 & \\ \text {-Presente } & 58 & 37 & 75,5 & 21 & 61,8 & 0,179\end{array}$

Fonte: Elaborada pelo pesquisador.

4.3.4 Expressão dos marcadores em relação ao escore de Gleason

Com relação à agressividade tumoral dada pelo grau de Gleason, os marcadores Ezrin, Radixin, Moesin e CD44V6 não apresentaram diferenças significativas quando comparado Gleason $=6$ com Gleason $=7$, permanecendo a ausência da expressão de: Ezerin em $51,9 \%$ e $48,4 \%$, Radixin $82,7 \%, 83,9 \%$ e Moesin $76,9 \%$, 83,9\% respectivamente e ao contrário a presença da expressão do CD44V6 69,2\% e 71,0 respectivamente. 
Tabela 8 - Relação entre o escore de Gleason e a presença de marcadores imunoistoquímicos, na amostra de pacientes com adenocarcinoma acinar usual da próstata.

\begin{tabular}{|c|c|c|c|c|c|c|}
\hline \multirow{2}{*}{$\begin{array}{l}\text { Marcador } \\
\text { Bioquímico }\end{array}$} & \multirow[t]{2}{*}{ Total } & \multicolumn{2}{|c|}{$\begin{array}{l}\text { Escore de } \\
\text { Gleason } \\
\qquad 2 \text { a } 6\end{array}$} & \multicolumn{2}{|c|}{$\begin{array}{l}\text { Escore de } \\
\text { Gleason } \\
7 \text { a } 10\end{array}$} & \multirow[t]{2}{*}{ Valor-p } \\
\hline & & $\mathbf{N}$ & $\%$ & $\mathbf{N}$ & $\%$ & \\
\hline
\end{tabular}

Ezrin:

$\begin{array}{lllllll}\text {-Ausente } & 42 & 27 & 51,9 & 15 & 48,4 & \\ \text {-Presente } & 41 & 25 & 48,1 & 16 & 51,6 & 0,755\end{array}$

Radixin:

$\begin{array}{lcccccc}\text {-Ausente } & 69 & 43 & 82,7 & 26 & 83,9 & \\ \text {-Presente } & 14 & 9 & 17,3 & 5 & 16,1 & 0,890\end{array}$


Moesin:

-Ausente

66

40

76,9

$26 \quad 83,9$

-Presente

17

12

23,1

$5 \quad 16,1$

0,448

CD44V6:

\begin{tabular}{lrrrrrr}
- Ausente & 25 & 16 & 30,8 & 9 & 29,0 & \\
-Presente & 58 & 36 & 69,2 & 22 & 71,0 & 0,867 \\
& & & & & & \\
\hline
\end{tabular}

Fonte: Elaborada pelo pesquisador.

\subsubsection{Expressão dos marcadores em relação ao estadiamento clínico}

$\mathrm{Na}$ tabela 9, encontramos uma diminuição na expressão de toda família ERM, com diferença estatística para o Ezrin $(61,4 \%)$, quando comparado o estádio T2, 3 com o estádio T1 nos parecendo que o aumento do estádio do tumor leva a uma diminuição da expressão da família ERM. Nota-se um aumento da expressão do CD44V6 $(68,4 \%)$. 
Tabela 9 - Relação entre o estádio clínico do tumor e a presença de marcadores imunoistoquímicos, na amostra de pacientes com adenocarcinoma acinar usual da próstata.

\begin{tabular}{c|c|c|c|c|c|c}
\hline \multirow{2}{*}{ Marcador } & \multirow{2}{*}{ Bioquímico } & \multicolumn{2}{|c|}{ Total } & \multicolumn{2}{|c|}{ Estágio t1 } & \multicolumn{2}{|c}{ Estágio t2 ou t3 } & \multirow{2}{*}{ Valor-p } \\
\cline { 3 - 4 } & & $\mathrm{N}$ & $\%$ & $\mathrm{~N}$ & $\%$ & \\
\hline
\end{tabular}

Ezrin:

$\begin{array}{lrrrrrr}\text {-Ausente } & 44 & 9 & 31,0 & 35 & 61,4 & \\ \text {-Presente } & 42 & 20 & 69,0 & 22 & 38,6 & 0,008\end{array}$

Radixin:

$\begin{array}{lllllll}- \text { Ausente } & 72 & 23 & 79,3 & 49 & 86,0 & \\ \text {-Presente } & 14 & 6 & 20,7 & 8 & 14,0 & 0,429\end{array}$




\section{Moesin:}

$\begin{array}{lrrrrrr}\text {-Ausente } & 68 & 20 & 69,0 & 48 & 84,2 & \\ \text {-Presente } & 18 & 9 & 31,0 & 9 & 15,8 & 0,100\end{array}$

CD44V6:

$\begin{array}{lllllll}\text {-Ausente } & 25 & 7 & 24,1 & 18 & 31,6 & \\ \text {-Presente } & 61 & 22 & 78,9 & 39 & 68,4 & 0,472\end{array}$

Fonte: Elaborada pelo pesquisador.

\subsubsection{Expressão dos marcadores em relação ao estadiamento anatomopatológico}

Na tabela 10, observamos o estádio patológico das lesões, comparando o estádio t2, doença confinada ao órgão, com t3 e t4, presença de doença extra-prostática ou invasão de órgãos vizinhos.

O Ezrin apresenta-se ausente em $51,6 \%$ e $50 \%$ do t2 e t3, 4 respectivamente, já o Radixin chama atenção pela ausência em $85,5 \%$ e $79,2 \%$ das amostras e Moesin está ausente em 77,4\% e $83,3 \%$. O CD44V6 manteve-se presente em $69,4 \%$ e $75,0 \%$ no t2 e t3, 4 respectivamente. 
Tabela 10 - Relação entre o estádio patológico do tumor e a presença de marcadores imunoistoquímicos, na amostra de pacientes com adenocarcinoma acinar usual da próstata.

\begin{tabular}{c|c|c|c|c|c|c}
\hline \multirow{2}{*}{ Marcador } & \multirow{2}{*}{ Total } & \multicolumn{2}{|c|}{ Estádio t2 } & \multicolumn{2}{|c|}{ Estádio t3 ou t4 } & \multirow{2}{*}{ Valor-p } \\
\cline { 3 - 6 } Bioquímico & & & & & \\
& & $N$ & $\%$ & $N$ & $\%$ & \\
\hline
\end{tabular}

Ezrin:

$\begin{array}{lrrrrrr}\text {-Ausente } & 44 & 32 & 51,6 & 12 & 50,0 & \\ \text {-Presente } & 42 & 30 & 48,4 & 12 & 50,0 & 0,893\end{array}$

Radixin:

$\begin{array}{llllll}\text {-Ausente } & 72 & 53 & 85,5 & 19 & 79,2\end{array}$




\begin{tabular}{lllllll}
\hline -Presente & 14 & 9 & 14,5 & 5 & 20,8 & 0,477
\end{tabular}

Moesin:

$\begin{array}{lrrrrrr}\text {-Ausente } & 68 & 48 & 77,4 & 20 & 83,3 & \\ \text {-Presente } & 18 & 14 & 22,6 & 4 & 16,7 & 0,545\end{array}$

CD44V6:

$\begin{array}{llllll}\text {-Ausente } & 25 & 19 & 30,6 & 6 & 25,0\end{array}$

$\begin{array}{lllllll}\text {-Presente } & 61 & 43 & 69,4 & 18 & 75,0 & 0,605\end{array}$

Fonte: Elaborada pelo pesquisador.

4.3.8 Expressão dos marcadores em relação às biópsias positivas

Não houve diferença significativa entre a proporção de biópsias positivas e os marcadores estudados, sendo achado importante um aumento da expressão do Ezrin $(65,2 \%)$ nas amostras com maior proporção de fragmentos positivo.

Tabela 11 - Proporção de amostras de biópsias positivas, segundo a presença de marcadores imunoistoquímicos, numa amostra de pacientes com adenocarcinoma acinar usual da próstata.

\begin{tabular}{c|c|c|c|c}
\hline Marcador & Total & $\begin{array}{c}\text { Proporção } \\
8 \text { a } 49 \%\end{array}$ & $\begin{array}{c}\text { Proporção } \\
50 \text { a } 100 \%\end{array}$ & Valor-p \\
\hline
\end{tabular}




\begin{tabular}{l|l|l|l|l|l|l}
\hline & & $\mathbf{N}$ & $\%$ & $\mathbf{N}$ & $\%$ & \\
\hline
\end{tabular}

Ezrin:

-Ausente 24

-Presente 24

16

59,3

8

34,8

Presente

26

11

40,7

15

65,2

0,084

Radixin:

-Ausente

43

24

89,0

19

82,6

-Presente

7

$3 \quad 11,0$

4

17,4

0,689

Moesin:

-Ausente

-Presente

42

22
5

81,5
18,5

20

87,0

8

5

18,5

3

13,0

0,711

CD44V6:

\begin{tabular}{lcccccc}
-Ausente & 14 & 9 & 33,3 & 5 & 21,7 & \\
-Presente & 36 & 18 & 66,7 & 18 & 78,3 & 0,363 \\
\hline
\end{tabular}

Fonte: Elaborada pelo pesquisador.

4.3.9 Expressão dos marcadores em relação à recidiva laboratorial

Definimos recidiva laboratorial quando ocorre elevação do PSA após a cirurgia, provável presença de doença microscópica. Observamos nesta tabela que o Ezrin apresenta-se ausente em $43,5 \%$ e presente em $56,5 \% \%$, o Radixin está ausente em $88,3 \%$ e presente em $11,7 \%$, já o Moesin esta ausente em $82,6 \%$ e presente em $17,4 \%$ das amostras de recidiva laboratorial. O CD44V6 está presente em $73,9 \%$ e ausente em $26,1 \%$ dos casos. 
Tabela 12 - Ocorrência de recidiva laboratorial (VCDL ou MCDL) nos casos com adenocarcinoma acinar usual da próstata, segundo a presença dos marcadores imunoistoquímicos.

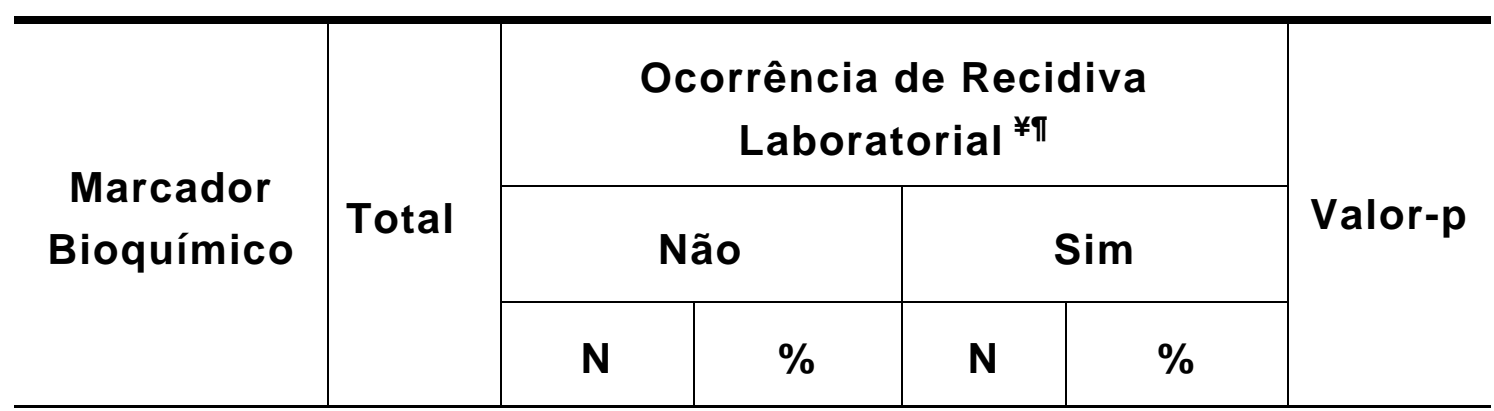

Ezrin:

-Ausente

39

$29 \quad 55,8$

$10 \quad 43,5$

-Presente

36

2344,2

1356,5

0,326

Radixin:

$\begin{array}{llllll}\text {-Ausente } & 62 & 44 & 84,6 & 19 & 88,3\end{array}$




\begin{tabular}{lcccccc}
\hline -Presente & 13 & 8 & 15,4 & 4 & 11,7 & 0,521 \\
Moesin: & & & & & & \\
-Ausente & 58 & 39 & 75,0 & 19 & 82,6 & \\
-Presente & 17 & 13 & 25,0 & 4 & 17,4 & 0,468 \\
CD44V6: & & & & & & \\
-Ausente & 23 & 17 & 32,7 & 6 & 26,1 & \\
-Presente & 52 & 35 & 67,3 & 17 & 73,9 & 0,567 \\
& & & & & & \\
\hline
\end{tabular}

Fonte: Elaborada pelo pesquisador.

${ }^{*} \mathrm{VCDL}=$ Vivo com doença laboratorial; $\mathrm{MCDL}=$ Morto com doença laboratorial.

Categoria de Referencia: Vivo sem doença ou morto por outra causa.

\subsubsection{Expressão dos marcadores em relação à recidiva clínica}

$\mathrm{Na}$ análise da recidiva clínica observamos que existe uma predominância da diminuição da expressão dos marcadores Radixin $90,9 \%$ e Moesin $90,9 \%$ e um aumento da expressão do Ezrin $54,6 \%$ e CD44V6 em $81,8 \%$ dos casos. Nenhum dos marcadores demonstrou significância estatística. 
Tabela 13 - Ocorrência de recidiva clínica (VCD ou MCD) entre pacientes com adenocarcinoma acinar usual da próstata, segundo a presença de marcadores imunoistoquímicos.

\begin{tabular}{|c|c|c|c|c|c|c|}
\hline \multirow{3}{*}{$\begin{array}{c}\text { Marcador } \\
\text { Bioquímico }\end{array}$} & \multirow{3}{*}{ Total } & \multicolumn{4}{|c|}{ Ocorrência de Recidiva Clínica ${ }^{¥ q}$} & \multirow{3}{*}{ Valor-p } \\
\hline & & \multicolumn{2}{|c|}{ Não } & \multicolumn{2}{|c|}{ Sim } & \\
\hline & & $\mathbf{N}$ & $\%$ & $\mathbf{N}$ & $\%$ & \\
\hline
\end{tabular}

Ezrin:

$\begin{array}{lllllll}\text {-Ausente } & 34 & 29 & 55,8 & 5 & 45,4 & \\ \text {-Presente } & 29 & 23 & 44,2 & 6 & 54,6 & 0,533\end{array}$

Radixin: 


\begin{tabular}{lrrrrrr}
\hline -Ausente & 54 & 44 & 84,6 & 10 & 90,9 & \\
-Presente & 9 & 8 & 15,4 & 1 & 9,1 & 1,000
\end{tabular}

Moesin:

-Ausente

49

3975,0

1090,9

-Presente

14

1325,0

19,1

0,430

CD44V6:

\begin{tabular}{lllllll}
-Ausente & 19 & 17 & 32,7 & 2 & 18,2 & \\
-Presente & 44 & 35 & 67,3 & 9 & 81,8 & 0,480 \\
& & & & & & \\
\hline
\end{tabular}

Fonte: Elaborada pelo pesquisador.

${ }^{\sharp} \mathrm{VCD}=$ Vivo com doença; $M C D=$ Morto com doença.

"Categoria de Referencia: Vivo sem doença ou morto por outra causa.

\subsubsection{Expressão dos marcadores em relação à recidiva global}

Na tabela 14 avaliamos a recidiva global, ou seja, pacientes que foram operados e apresentaram elevação do PSA, posteriormente metástases e óbito. Observamos diminuição da expressão dos marcadores Radixin $86,3 \%$ e Moesin $85,3 \%$ e aumento da expressão do Ezrin 55,9\% e do CD44V6 em 76,5\%, porém não há diferença significativa quando comparado com os pacientes vivos sem doença. 
Tabela 14 - Ocorrência de recidiva global (VCD ou MCD ou VCDL ou MCDL) entre pacientes com adenocarcinoma acinar usual da próstata, segundo a presença de marcadores imunoistoquímicos.

\begin{tabular}{|c|c|c|c|c|c|c|}
\hline \multirow{3}{*}{$\begin{array}{l}\text { Marcador } \\
\text { Bioquímico }\end{array}$} & \multirow{3}{*}{ Total } & \multicolumn{4}{|c|}{ Ocorrência de Recidiva $a^{¥ q}$} & \multirow{3}{*}{ Valor-p } \\
\hline & & \multicolumn{2}{|c|}{ Não } & \multicolumn{2}{|c|}{ Sim } & \\
\hline & & $\mathbf{N}$ & $\%$ & $\mathbf{N}$ & $\%$ & \\
\hline
\end{tabular}

Ezrin:

$\begin{array}{lllllll}\text {-Ausente } & 44 & 29 & 55,8 & 15 & 44,1 & \\ \text {-Presente } & 42 & 23 & 44,2 & 19 & 55,9 & 0,291\end{array}$


Radixin:

-Ausente

72

4484,6

$28 \quad 86,3$

-Presente

14

$8 \quad 15,4$

613,7

0,781

Moesin:

-Ausente

68

3975,0

2985,3

-Presente

18

1325,0

$5 \quad 14,7$

0,251

CD44V6:

-Ausente

25

$17 \quad 32,7$

823,5

-Presente

61

$35 \quad 67,3$

$26 \quad 76,5$

0,360

Fonte: Elaborada pelo pesquisador.

${ }^{\sharp} \mathrm{VCD}=$ Vivo com doença; $\mathrm{MCD}=$ Morto com doença; $\mathrm{VCDL}=$ Vivo com doença laboratorial; MCDL=Morto com doença laboratorial.

"Categoria de Referencia: Vivo sem doença ou morto por outra causa.

\subsubsection{Expressão dos marcadores em relação à ocorrência de óbito}

A comparação dos níveis de expressão dos marcadores teciduais em relação a óbitos nesta amostra, observamos ausência da expressão dos marcadores Radixin $83,3 \%$ e Moesin em $100 \%$ dos casos, com aumento da expressão do CD44V6 83,3\%, o Ezrin esteve presente em $50 \%$ dos casos. Não foram observadas diferenças estatísticas 
Tabela 15 - Ocorrência de óbito, entre os pacientes com adenocarcinoma acinar usual da próstata, segundo a presença de marcadores imunoistoquímicos.

\begin{tabular}{|c|c|c|c|c|c|c|}
\hline \multirow{3}{*}{$\begin{array}{l}\text { Marcador } \\
\text { Bioquímico }\end{array}$} & \multirow{3}{*}{ Total } & \multicolumn{4}{|c|}{ Ocorrência de Óbito } & \multirow{3}{*}{ Valor-p } \\
\hline & & \multicolumn{2}{|c|}{ Não } & \multicolumn{2}{|c|}{ Sim } & \\
\hline & & $\mathbf{N}$ & $\%$ & $\mathbf{N}$ & $\%$ & \\
\hline \multicolumn{7}{|l|}{ Ezrin: } \\
\hline -Ausente & 44 & 41 & 51,2 & 3 & 50,0 & \\
\hline
\end{tabular}


-Presente

42

39

48,8

3

$50,0 \quad 1,000$

Radixin:

-Ausente

72

67

83,8

5

83,3

-Presente

14

13

16,2

1

16,7

1,000

Moesin:

-Ausente

68

62

77,5

6

100

-Presente

18

18

22,5

0

0

0,336

CD44V6:

\begin{tabular}{lllllll}
-Ausente & 25 & 24 & 30,0 & 1 & 16,7 & \\
-Presente & 61 & 56 & 70,0 & 5 & 83,3 & 0,667 \\
& & & & & & \\
\hline
\end{tabular}

Fonte: Elaborada pelo pesquisador.

\subsection{Expressão dos marcadores e sobrevida livre de doença}

A análise da expressão do Ezrin, Radixin, Moesin e do CD44V6 de acordo com a sobrevida livre de doença dos pacientes portadores de câncer da próstata está ilustrada nos gráficos 2 a 5 . A presença da expressão do Ezrin esteve muito próxima da significância estatística quando relacionada com a piora da sobrevida destes pacientes. Os marcadores Radixin, Moesin e CD44V6 não 
apresentaram diferenças estatísticas com relação à sobrevida.

iença de EZRIN

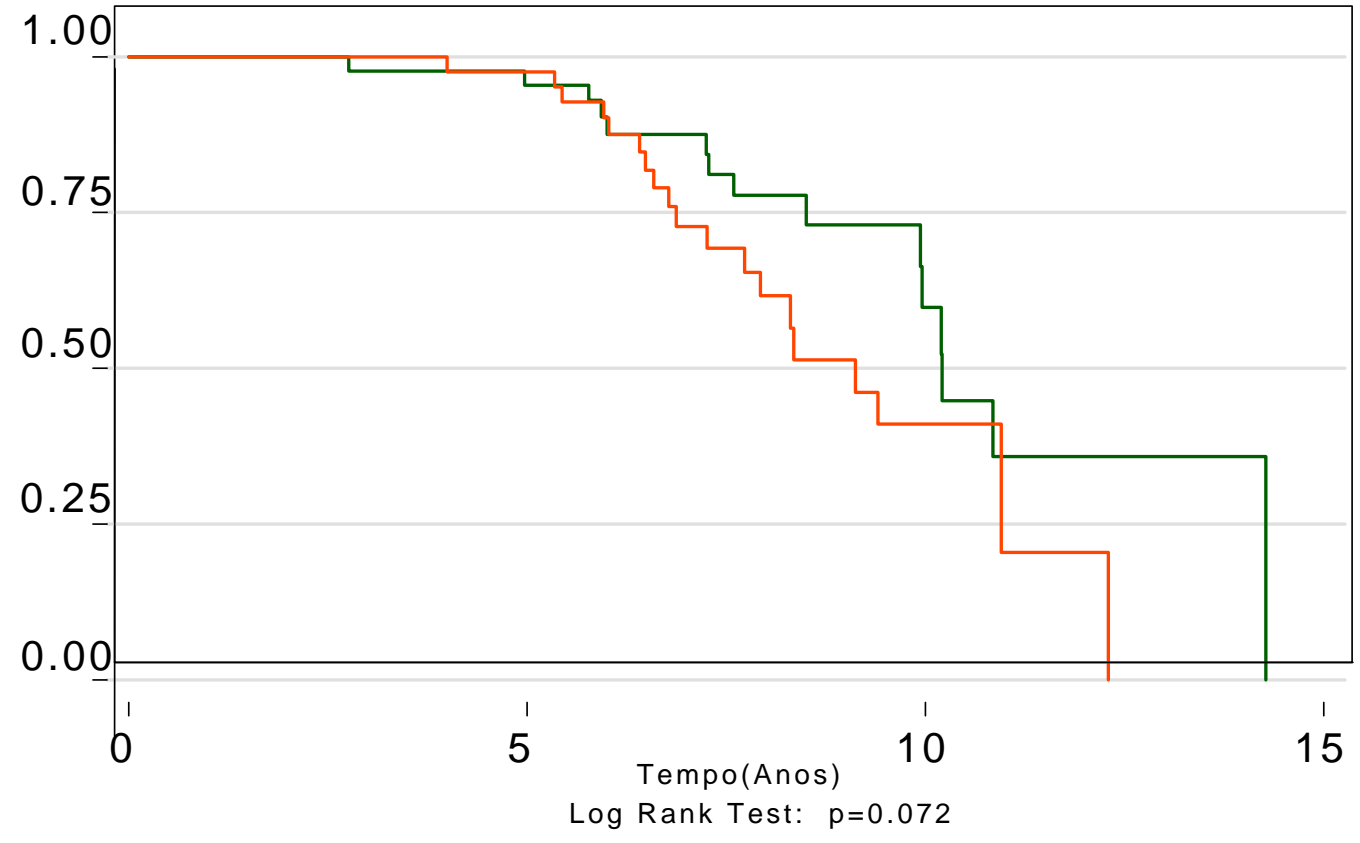

$E Z R I N=0 \quad E Z R I N=1$

$$
\begin{aligned}
& 0=\text { Ausência } \\
& 1=\text { Presença }
\end{aligned}
$$

Gráfico 2 - Ocorrência de sobrevida livre de doença, segundo a presença de Ezrin.

Fonte: Elaborada pelo pesquisador.

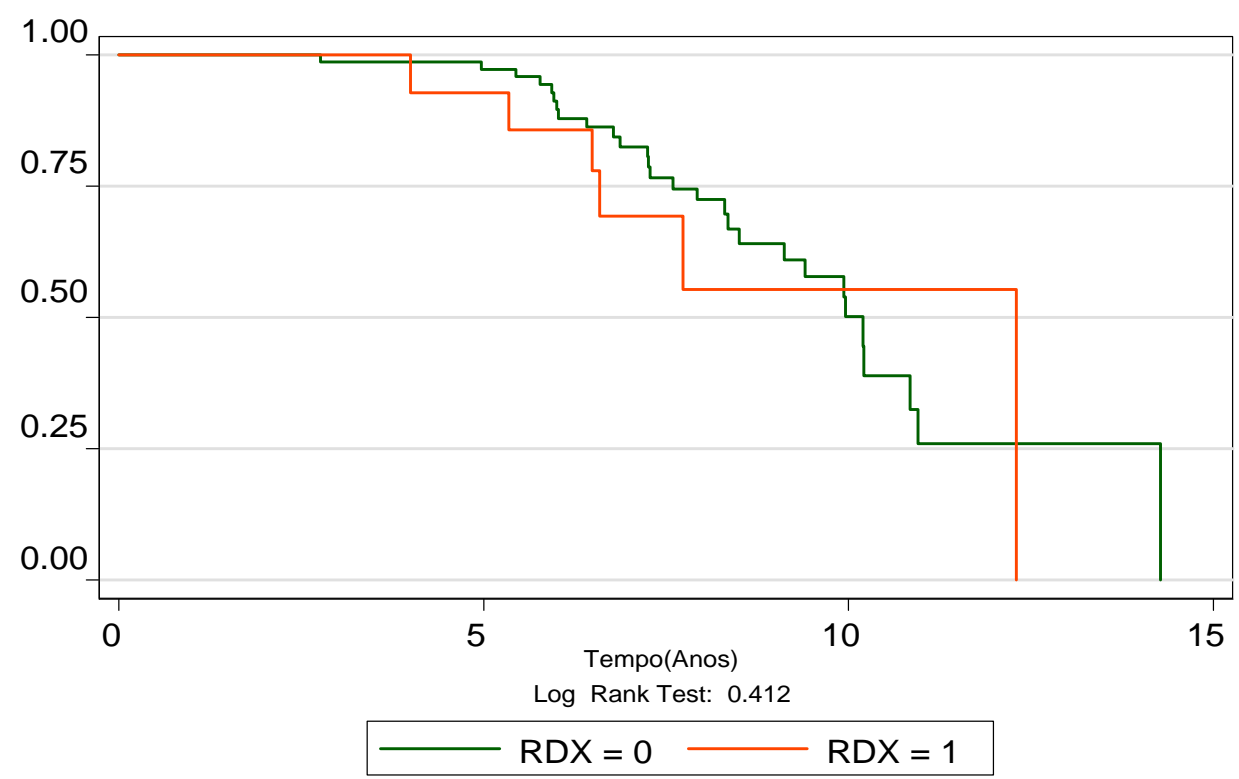


Gráfico 3 - Ocorrência de sobrevida livre de doença, segundo a presença de Radixin $(0,412)$.

Fonte: Elaborada pelo pesquisador.

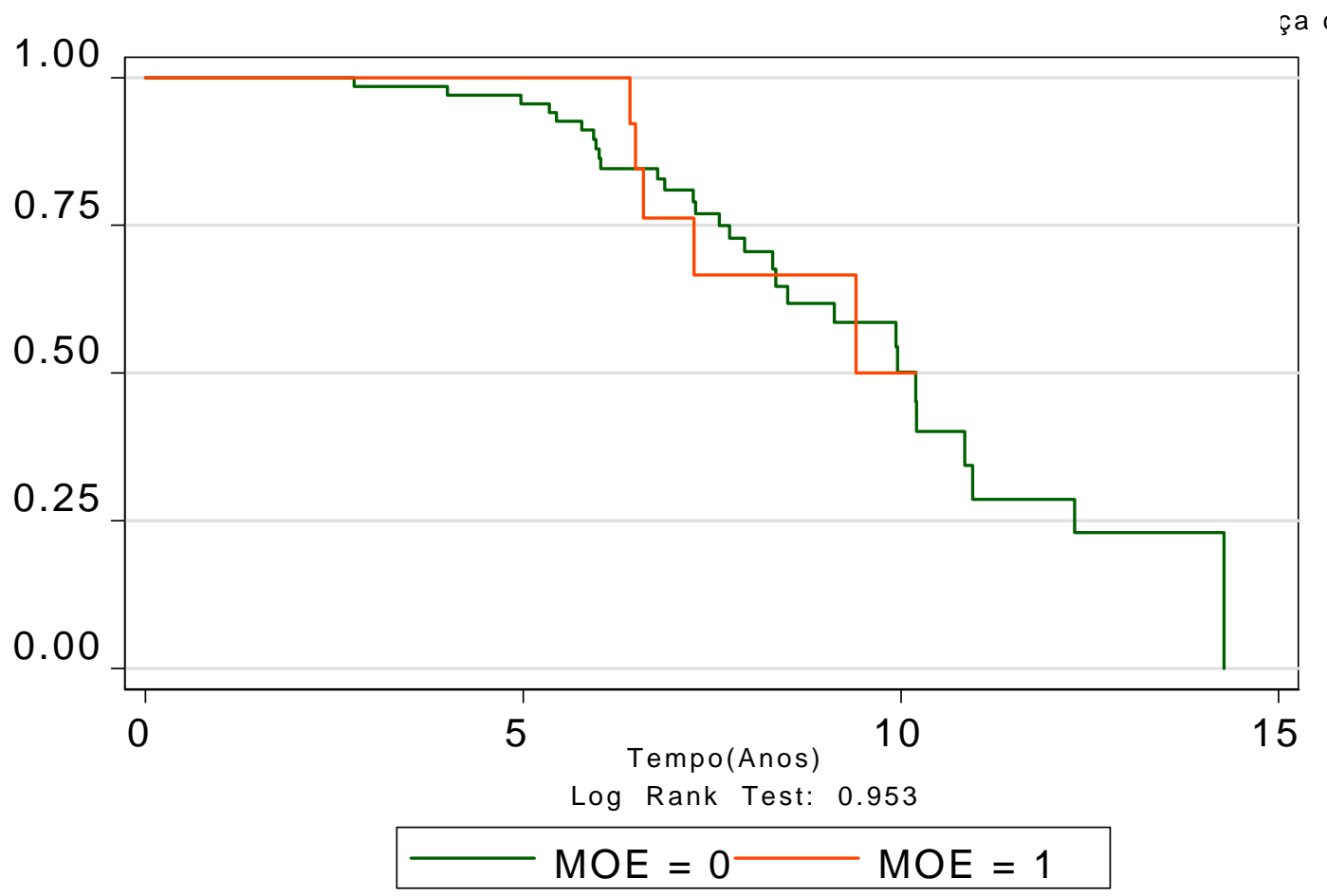

a de MOESIN

Gráfico 4 - Ocorrência de sobrevida livre de doença segundo a presença de Moesin.

Fonte: Elaborada pelo pesquisador. 


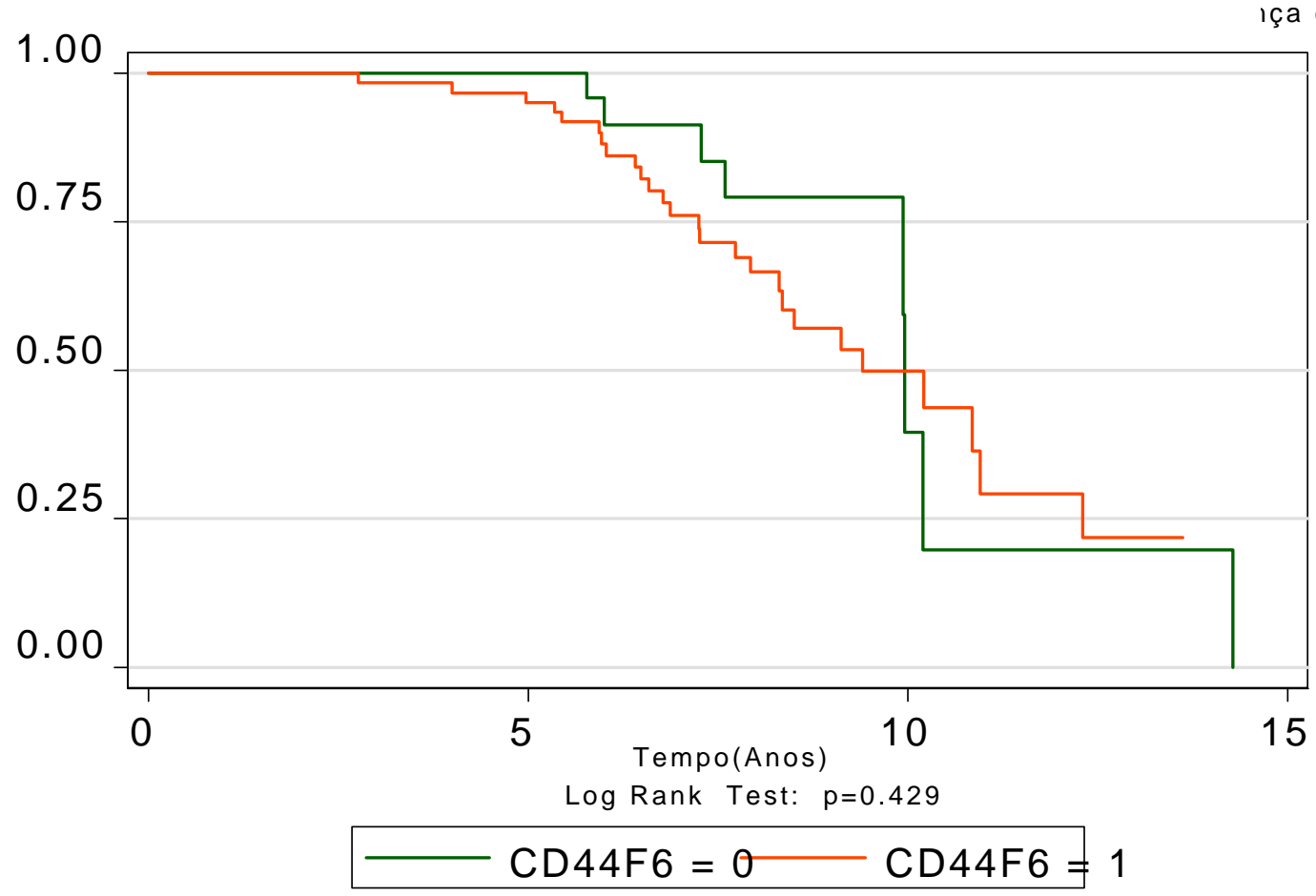

lça de CD44V6

Gráfico 5 - Ocorrência de sobrevida livre de doença segundo a presença de CD44V6.

Fonte: Elaborada pelo pesquisador.

4.5 Análise multivariada dos fatores prognóstico clínicos e moleculares do adenocarcinoma usual de próstata

A tabela 16 apresenta a análise multivariada relacionando os fatores prognósticos clínicos (PSA, Escore de Gleason e Estadiamento) e a molécula Ezrin, sendo observada uma diferença estatisticamente significante referente ao estadiamento patológico e da molécula Ezrin. 
Tabela 16 - Relação entre fatores prognóstico clínico e molécula Ezrin e a ocorrência de sobrevida livre de doença no adenocarcinoma acinar usual da próstata, ajustada e não ajustada para potenciais confundidores.

\begin{tabular}{l|c|c|c}
\hline \multirow{2}{*}{\multicolumn{1}{c|}{ Variável }} & \multicolumn{2}{c|}{$\begin{array}{c}\text { Razão de Densidade de } \\
\text { Incidência }\end{array}$} & \multirow{2}{*}{ Valor-p } \\
\cline { 2 - 3 } & Pontual & I.C. 95\% & \\
\hline Ezrin $^{\varepsilon}$ & 1,89 & $0,94-3,83$ & 0,076 \\
PSA pré-operatório & 1,30 & $0,63-2,67$ & 0,480 \\
Escore de Gleason & 2,80 & $1,37-5,73$ & 0,005 \\
Estádio histopatológico & 4,82 & $2,41-9,67$ & $<0,001$ \\
ModELO MULTIVARIADO: & & & \\
Ezrin & 2,21 & $1,02-4,79$ & $<0,045$ \\
Escore de Gleason & 2,06 & $0,99-4,31$ & 0,053 \\
Estágio histopatológico & 4,47 & $2,10-9,52$ & $<0,001$ \\
\hline
\end{tabular}

Fonte: Elaborada pelo pesquisador.

$\S \mathrm{VCD}=$ Vivo com doença; $M C D=$ Morto com doença; $\mathrm{VCDL}=$ Vivo com doença laboratorial; MCDL=Morto com doença laboratorial.

ๆ Hazard Ratio

* Categoria de Referencia: Vivo sem doença ou morto por outra causa.

£ Análise univariada 


\section{DISCUSSÃO}

A prostatectomia radical é uma forma definitiva de tratamento do câncer localizado da próstata. Entretanto, aproximadamente 40\% dos pacientes tratados pela prostatectomia radical apresentaram progressão da doença, mesmo com a doença confinada ao órgão. Acurácia previsão do risco de recorrência é útil para se considerar uma terapia adjuvante ou alguma forma de tratamento investigacional. Atualmente, aos nossos conhecimentos não existe nenhum marcador tumoral prognóstico que avalie quais pacientes se beneficiaram com a prostatectomia radical. É bem conhecido que pacientes com o mesmo estádio e escore de Gleason possam apresentar diferentes prognósticos. Para se fazer uma precoce avaliação da agressividade do tumor é crucial o desenvolvimento de novos marcadores moleculares biológicos.

No entendimento dos processos envolvidos na carcinogênese, a utilização de marcadores moleculares teve um desenvolvimento muito rápido nas últimas décadas, principalmente devido à melhoria nas técnicas que permitiram a manipulação do material genético (Eisen et al., 1998). A detecção de células tumorais circulantes e da 
doença tumoral residual mínima ressurgiu há cerca de vinte anos com o advento da imunohistoquímica.

Testes imunocitológicos foram desenvolvidos para detectar células tumorais na medula óssea e em tumores sólidos (Gion; Gasparini, 2002). A aplicação da imunohistoquímica tem contribuído efetivamente como um recurso a mais no campo diagnóstico das neoplasias, principalmente nas lesões pouco diferenciadas morfologicamente. Este recurso tem permitido, em algumas situações, a classificação de lesões com base na imunodetecção de seu perfil antigênico.

Estudos demonstram que a expressão do CD44 e de suas isoformas estão alteradas em diferentes tipos de neoplasias malignas (Kanke et al., 2000), sendo observado um padrão de expressão de marcada diversidade (Morris et al., 2001). A expressão alterada da referida molécula de adesão está relacionada com os processos de progressão tumoral e de metástase (Hudson et al.,1996, Oliveira; Odell, 1997).

As isoformas do CD44 são expressas nas células malignas, especialmente o CD44V6, mas seu padrão de expressão nos diferentes tipos de neoplasias malignas é discutido, uma vez que o CD44V6 pode atuar como molécula de adesão promotora de 
crescimento e invasão tumoral ou como cofator de supressão de tumor regulando o crescimento tumoral (Gong et al., 2005).

O CD44V6 tem sido clonado e quando o seu cDNA é transferido para células de carcinoma pancreático com baixo poder metastático, ocorre o aumento do potencial metastático destas células. O uso de anticorpos monoclonais para CD44V6 inibem o crescimento destas metástases, indicando o papel crucial do CD44V6 em câncer metastático.

$\mathrm{Na}$ próstata, estudos imunohistoquímicos são mais conflitantes. Tem sido observada uma associação entre níveis aumentada da expressão do CD44V6 e a sobrevida curta, prognóstico pobre e a presença de metástase (Takahashi et al., 1998; Jung, K.; Jung, M., 1995; Paradis et al., 1999). Por outro lado, há trabalhos que mostram uma redução ou perda da expressão do CD44V6 associada com os referidos processos citados anteriormente (Aaltomaa et al., 2001; De Marzo et al., 1998; Noordzij et al., 1999).

Estudos in vitro com células tumorais prostáticas demonstraram aumento da expressão do CD44 (Liu, 1994). O aumento da expressão do CD44V6 no câncer de próstata foi também demonstrado por Takahashi et al. (2007) tendo o mesmo demonstrado que a expressão desta molécula no câncer de próstata estaria relacionado com a diferenciação tumoral, mas não tinha relação com estádio clínico ou prognóstico. 
Jung et al. (1996) avaliaram imunohistoquimicamente a expressão do CD44V6 em casos controles $(n=30)$, pacientes com hiperplasia benigna da prostática $(\mathrm{HBP}=30)$, pacientes com câncer de próstata localizado T1, 2, 3, N0, M0 $(n=30)$ e pacientes com câncer da próstata localmente avançado ou metastático T3, 4, N1, 2, M1 ( $n=19)$. A expressão do CD44V6 não teve significância estatística entre os quatro grupos estudados, como também não houve diferenças significativas quando comparados os dois grupos de câncer prostáticos. Em contraste com outros trabalhos, não houve relação da expressão do CD44V6 com o prognóstico dos pacientes portadores de câncer da próstata.

Duzentas e nove biopsias de pacientes portadores de câncer da próstata foram estudadas por Aaltomaa et al. (2001) com o objetivo de verificar a influência da expressão do CD44 e suas isoformas CD44v3 e CD44V6 no prognóstico destes pacientes. A baixa expressão do CD44 e CD44V6 estava relacionada com aumento do estadiamento, presença de metástases, escore de Gleason alto, aneuploidia do DNA, infiltração perineural e alto índice mitótico com pobre sobrevida. Os autores concluíram que a baixa expressão do CD44 e CD44V6 esta relacionada com a agressividade tumoral e prognóstico desfavorável do câncer da próstata.

A fim de determinar a correlação entre a expressão do CD44V6 e aspectos clínico-patológicos do câncer da próstata, De Marzo et al. (1998) estudou 94 pacientes portadores desta neoplasia e 
observaram uma diminuição da expressão do CD44V6 no tumor primário e perda da expressão com o aumento do escore de Gleason. Observou também ausência de expressão nas metástases linfonodais $(n=27)$ e nas metástases ósseas $(n=21)$, concluindo-se que a baixa expressão do CD44 e CD44V6 esta relacionado com o aumento da agressividade e presença de metástases no câncer da próstata.

Em trabalho realizado por Noordzij et al. (1997) tendo sido estudado a correlação da expressão do CD44V6 em dois grupos de pacientes, um com portadores de câncer da próstata localizado $(n=23)$ e outro com a doença avançada $(n=23)$ tratados pela prostatectomia radical, foi observado uma diminuição da expressão do CD44V6 no tumor primário e ausência da expressão nos casos com metástases, relacionando-se este achado, com a piora do prognostico destes pacientes. $O$ autor conclui que esta ausência da expressão do CD44V6 pode ser usada para predizer pacientes com prováveis linfonodos positivos.

Nas condições do nosso estudo, verificamos que houve expressão da proteína de adesão celular CD44V6 em 70,9\% dos casos estudados, porém, esta expressão não foi estatisticamente significativa quando comparada com os fatores prognósticos (PSA, escore de Gleason e estadiamento) nem com a sobrevida livre de doença. No entanto é nítido o aumento da expressão desta molécula em todas as variáveis estudadas. Acreditamos que estudos futuros 
com maior número de casos, possam trazer significância clínica, possibilitando um melhor entendimento da molécula CD44V6 no desenvolvimento e progressão do câncer da próstata.

A idade é um fator de risco importante, ganhando um significado especial no câncer da próstata, uma vez que tanto a incidência como a mortalidade aumentam exponencialmente após a idade dos 50 anos, baseado nisto avaliamos a expressão destes marcadores comparando pacientes com menos de 65 anos versus pacientes com mais de 65 anos, observamos que não houve diferença estatística da expressão das moléculas estudadas entre os dois grupos.

Um achado de significância no nosso estudo foi a diminuição da expressão do Radixin e Moesin quando comparados com os valores de PSA pré-operatório. Esta diminuição da expressão foi estatisticamente significante $(p<0,008$ e $p<0,044)$ para os pacientes portadores de PSA > 10ng/ml no pré-operatório. Como sabemos, os níveis do PSA no sangue dependem diretamente do volume de tecido prostático benigno ou maligno existente. Nos casos do adenocarcinoma da próstata, cada grama de tecido neoplásico aumenta os níveis séricos de PSA de $3,5 \mathrm{ng} / \mathrm{ml}$ (Yang, 1987), o que indica que quanto maior os valores de PSA, maior é o volume de tumor existente no paciente. A dosagem do PSA sérico possui, atualmente, um valor prognóstico amplamente aceito, sendo 
considerado como categoria I, no consenso do College of American Pathologists (Bostwick, 2000).

O PSA pré-tratamento de $20 \mathrm{ng} / \mathrm{ml}$ ou mais, tem valor preditivo para a sobrevida de pacientes com câncer da próstata localizado (Buhmeida et al., 2006). Porém, o valor prognóstico deste marcador para a sobrevida em longo prazo ainda não está bem determinado, ao contrário do que ocorre com a classificação de Gleason, status patológico dos linfonodos e estádio tumoral.

Outros estudos defendem o ponto de coorte de $40 \mathrm{ng} / \mathrm{ml}$ ou mais, como tendo importância prognóstica. Já as tabelas de Partin e Kattan, os nomogramas mais utilizados atualmente, os níveis de PSA são divididos em: 0 a 2,5;2,6 a 4,0;4,1 a 6,0;6,1 à 10,0 e maior que 10ng/ml (Partin et al., 2001).

O uso da densidade de PSA como marcador prognóstico clínico, em substituição ao PSA total, é um tema controverso na literatura, com estudos indicando sua superioridade Freedland et al. (2002) e outros apresentando resultados diametralmente opostos (Brassett et al., 2005). No estudo de Freedland et al. (2002), os resultados apontaram a densidade de PSA como forte marcador prognóstico pré-tratamento para achados patológicos e para recorrência de PSA. A estratificação do risco, utilizando este marcador e o Gleason da peça operatória, foi superior a que utiliza o PSA total e Gleason da peça operatória. A densidade de PSA é 
calculada dividindo-se o valor prévio de PSA $(\mathrm{ng} / \mathrm{ml})$ pelo peso da próstata retirada na cirurgia $(\mathrm{mg})$.

A velocidade do PSA e o percentual de PSA livre são outros derivados do PSA pesquisados que apresentou alguns achados favoráveis no seu papel como fator prognóstico. A velocidade de aumento do PSA, maior do que $2 \mathrm{ng} / \mathrm{ml}$ no ano anterior à prostatectomia radical, foi recentemente apontada como um marcador de maior risco de morte (D'AMICO et al., 2004).

A detecção do PSA sérico após tratamento curativo com a prostatectomia radical ou radioterapia, também chamada de recorrência bioquímica, tem sido o desfecho mais comumente considerado em estudos de fatores prognóstico do câncer da próstata localizado. A facilidade de seu uso em estudos vem do fato de ser um marcador incorporado à prática clínica, sendo utilizado periodicamente após o tratamento curativo com vistas á detecção de recidiva precoce para instituição de terapêutica de resgate (Scardino et al., 2006).

Também é usual a utilização do PSA pós-tratamento para distinguir recidiva local da recidiva à distância, sendo a elevação rápida do PSA, ou persistência deste logo após a cirurgia, considerada um sinal da existência de doença sistêmica. O nadir do PSA sérico, após a cirurgia ocorre em cerca de seis semanas após o tratamento, variando de acordo com os níveis séricos pré-tratamento (Ferreira; Koff, 2007). 
Recentemente, um estudo de coorte com 1.136 homens com diagnóstico de câncer da próstata localizado, tratados com prostatectomia radical com ou sem hormônioterapia, demonstrou a existência de associação entre recorrência bioquímica e a mortalidade específica pelo câncer da próstata (Albertsen et al., 2004). Os resultados deste estudo permitiram, também, distinguir dois grupos de risco de morte pela doença em até 10 anos depois do diagnóstico: pacientes com um tempo de duplicação dos níveis de PSA pós-tratamento maior e menor do que um ano.

Apesar de muito utilizado como desfecho em estudos prognósticos, o tempo entre recorrência bioquímica e eventos clinicamente relevantes, como o desenvolvimento de metástase e morte por câncer, ainda não está muito bem estabelecido. Em um grande estudo, com 1.997 pacientes, submetidos à prostatectomia radical e sem tratamento após recorrência bioquímica, foram seguidos por até 15 anos para a determinação da história natural após recorrência bioquímica (Pound et al., 1999).

Neste estudo o tempo médio entre a recorrência bioquímica e o desenvolvimento de metástase foi de oito anos, e de cinco anos entre o diagnóstico da doença metastática e o óbito. O tempo até a recorrência bioquímica, a classificação de Gleason e o tempo de duplicação de PSA foram as variáveis capazes de prever a probabilidade e o tempo para o desenvolvimento de metástase. 
Como se pode inferir nestes dados, o estudo dos níveis de PSA representa o parâmetro mais eficiente para se determinar atividade da doença, resposta ao tratamento e prognóstico dos pacientes com câncer de próstata. Este marcador, contudo não é seguro para se detectar precocemente ou estadiar a doença.

O achado da diminuição da expressão do Radixin e Moesin , pode ser que reflitam uma diminuição da adesividade das células neoplásicas, podendo, facilmente, estas se separarem do tumor primário e originar invasão loco-regional com posterior metástase linfonodal, e por fim metástase a distância. Sendo talvez esta a relação da diminuição da expressão destes marcadores em pacientes com PSA mais elevados. Estudos associando PSA, Radixin e Moesin serão necessários para se saber, se estas proteínas no futuro, possam ser utilizadas com marcador molecular para o diagnóstico desta neoplasia em estádio mais precoce.

$\mathrm{Na}$ análise multivariada relacionando os fatores prognósticos clínicos e moleculares do nosso trabalho, observamos que o estadiamento patológico e a proteína Ezrin tiveram significância estatística ( $p<0,001$ e $p<0,045$ respectivamente) com relação a sobrevida livre de doença dos pacientes portadores de câncer da próstata estudados.

Existem dois aspectos importantes para a definição de prognóstico do câncer da próstata localizado. O primeiro é a necessidade de se definir se o câncer é realmente restrito ao órgão, 
tendo em vista que apenas a doença localizada é passível de cura com as terapias radicais disponíveis. O segundo aspecto é a necessidade de se identificar os cânceres latentes, que não devem ser tratados.

A maior parte dos marcadores prognósticos pesquisados atualmente é oriunda da análise de espécies de prostatectomia radical. O ideal seria utilizar estes marcadores nas peças biopsiadas, antes da decisão terapêutica. Porém, em função da natureza heterogênea e multifocal do câncer da próstata, conseguir amostras representativas através de biópsias é muito difícil e a maioria destas técnicas ainda deve ser alvo de mais estudos (BUHMEIDA et al., 2006).

O estadiamento é uma etapa essencial para a definição do prognóstico e instituição da terapêutica adequada para cada paciente, em qualquer tipo de câncer. Embora, no caso específico do câncer da próstata, onde o estadiamento clínico é baseado, em grande parte, no toque retal, o estádio clínico possua importantes limitações, incluindo um percentual elevado de sub-estadiamentos, ele permanece como fator prognóstico e como avaliação indispensável para todos os pacientes com diagnóstico de câncer da próstata.

O estadiamento patológico refere-se ao reestadiamento do tumor após a cirurgia, baseando-se na classificação pTNM. É realizado mediante a análise patológica de todas as peças cirúrgicas, 
incluindo próstata, vesículas seminais e linfonodos pélvicos. As categorias $\mathrm{pT}, \mathrm{pN}$ e pM, são idênticas as categorias $T, N, M$, com exceção da categoria T1, que não existe na pTNM (Brasil, 2000).

A utilização do estádio patológico como desfecho de estudos prognósticos com pacientes tratados cirurgicamente, possui 0 conveniente de auxiliar na tomada de decisão na conduta clínica, como indicação de biópsia de linfonodos, extensão da técnica cirúrgica ou irradiação pélvica.

O estadiamento cirúrgico é mais confiável que o clínico, que frequentemente sub-estadia os pacientes. Além disso, é considerado um fator prognóstico "categoria I" pelo College of Americal Pathologists e pela Organização Mundial de Saúde (OMS), (Bostwick et al., 2000). Além de sua importância como desfecho em estudos com fatores prognósticos clínicos, a tendência é que seja, cada vez mais, incorporado à nomogramas voltados para a resolução de dilemas clínicos pós-tratamento, como a instituição de terapias adjuvantes.

$\mathrm{Na}$ nossa série de pacientes estudados tratados pela prostatectomia radical com linfadenectomia pélvica de 1995 a 2000 a sobrevida geral em 4 anos foi de $97,9 \%$ e aos 8 anos de $93,0 \%$. 0 estadiamento patológico foi um fator prognóstico independente na sobrevida destes pacientes. 
$\mathrm{Na}$ análise das curvas de sobrevida deste trabalho, observamos também que a presença da expressão da molécula Ezrin esta relacionada com a diminuição da sobrevida dos pacientes estudados. Recentes estudos demonstraram que a molécula Ezrin, produto do gen Vil2, desempenha papel crucial na disseminação de dois tumores pediátricos (osteossarcoma e rabdomiosarcoma).

Khanna et al. (2004) e Yu et al. (2004), estudando células da linhagem destes tumores com diferentes capacidade de metastatização, descobriram um aumento da expressão da molécula Ezrin nas células com alta capacidade de metastatizar e a transferência desta molécula para células com baixo potencial metastático, aumentava dramaticamente o potencial destas células em desenvolver metástase pulmonar em estudo experimental, demonstrando que o aumento da expressão do Ezrin confere aumento da capacidade de metastatizar destas células.

A identificação do Ezrin como um componente chave no processo de disseminação dos tumores pediátricos, nos auxiliou a um melhor entendimento entre as conexões da cadeia molecular, composta das proteínas de superfície celular, as vias de transdução de sinal, o núcleo e suas possíveis relações com infiltração tumoral e metástases. A interação existente entre o Ezrin e os receptores de superfície celular é bem demonstrada com a formação do complexo CD44/Ezrin, pois como sabemos a molécula Ezrin se liga com a 
cauda citoplasmática do CD44 que sabemos ter importância na migração celular de tumores invasivos.

Estudos demonstraram que o aumento da expressão do CD44 potencialmente leva a um aumento da expressão do Ezrin que se correlacionou com aumento da infiltração dos osteosarcomas. Ademais, o Ezrin tem sido associado com os receptores de fator de crecimento do hepatocito (HGF) que estão implicados com a progressão de osteosarcoma em cães e humanos. Ambos Ezrin e Hepatocyte Growth Factor (HGF) têm sido implicados no aumento da motilidade celular, sugerindo que Ezrin esta envolvido em mediar a invasão celular. Outra importante função do Ezrin é na formação de complexos de superfície celular que media a adesão célula-celula e célula-MEC.

Nestes complexos estão presentes a E-caderina e as integrinas. A perda da expressão da E-caderina ou a desregulação de sua função está relacionado com o aumento da disseminação metastática. Recentes evidências sugerem que a molécula Ezrin é importante na localização da E-caderina na membrana plasmática, células que expressam Ezrin tem um aumento da E-caderina intracelular, ocasionando uma diminuição de sua expressão e o contato entre as células e o aumento da expressão do Ezrin pode ter efeito similar, resultando em sequestro da E-caderina com diminuição da adesão celular. A interação entre célula e a matriz extracelular é mediada pelas integrinas, que também são 
importantes no processo de progressão tumoral. Especula-se que as integrinas estão envolvidas no processo de contenção das células tumorais, e a quebra das integrinas pela presença do Ezrin ou de outras proteínas da família ERM contribui significantemente para o aumento da sobrevida das células tumorais na circulação com a formação de novas micrometastases. Khanna et al. (2004) demonstrou que a supressão da expressão do Ezrin se correlacionam com a diminuição da sobrevida das células tumorais do osteosarcoma.

Na próstata, Valdman et al. (2008), observou o aumento da expressão do Ezrin, na neoplasia intraepitelial da próstata de alto grau, bem como no câncer da próstata, estando este achado relacionado com aumento do escore de Gleason e com a invasão das vesículas seminais, mas não tendo relação com a extensão extraprostática nem com a sobrevida livre de doença, o autor conclui que o Ezrin têm relação com os fatores prognósticos adversos no câncer da próstata, bem como, talvez tenha um importante papel no processo de carcinogenese, transformando tumores intraepiteliais em câncer prostático invasivo. Pesquisas futuras são necessárias para determinar a real função do Ezrin no câncer da próstata.

A análise de novos genes candidatos a marcadores de diagnóstico e prognóstico no câncer da próstata tem se tornado um grande desafio para urologistas, oncologistas e patologistas, pois sabemos que até o momento muitos permanecem com aplicações 
experimentais, provavelmente pela variabilidade nos métodos de detecção. Quando buscamos um marcador considerado ideal para aplicação clínica, gostaríamos que este possuísse as características de alta especificidade (para não ser detectado, por exemplo, em tumores benignos), alta sensibilidade (para ser detectado precocemente, ou seja, quando da atividade de pequeno agrupamento de células tumorais; ter um tecido de especificidade; ter boa correlação com os estádios do tumor e finalmente, ter uma boa correlação com o prognóstico (Sell, 1991).

No nosso estudo, o estadiamento patológico e a molécula Ezrin foram fator prognóstico independente para a sobrevida dos pacientes com câncer da próstata. No entanto, o estadiamento patológico só pode ser avaliado após a cirurgia, não evitando o procedimento, nem dando opção para outras terapias. O achado da molécula Ezrin, também como fator prognóstico independente, talvez nos permita, no futuro, o estudo desta molécula em biópsias, possibilitando avaliar a agressividade do tumor no pré-tratamento, sendo possível a escolha do tratamento ideal, bem como de terapias adjuvantes ou alguma forma de tratamento investigacional. Devemos prosseguir em busca de maiores informações a respeito da biologia molecular do câncer da próstata. 


\section{CONCLUSÃO}

1. Houve expressão imunoistoquímica dos Marcadores CD44V6 (61 casos, 70,9\%) e da Família ERM (Ezrin 42 casos 48,4\%; Radixin 14 casos $16,3 \%$ e Moesin 18 casos 20,9\%) no Adenocarcinoma Acinar Usual da Próstata.

2. A diminuição da expressão do Radixin (97\%) e do Moesin (91\%) foi estatisticamente significante $(p=0,008$ e $p=0,044)$ em relação ao fator prognóstico PSA pré-operatório acima de $10 \mathrm{ng} / \mathrm{ml}$ nos pacientes com adenocarcinoma da próstata estudados.

3. Na análise multivariada entre os fatores prognósticos clínico e moleculares observamos que a presença da expressão da molécula Ezrin teve significância estatística $(p<0,045)$ quando relacionada com a diminuição da sobrevida global dos pacientes estudados. Sendo um fator prognóstico independente na redução da sobrevida dos pacientes com câncer da próstata. 


\section{ANEXOS}

\section{ANEXO A - Classificação dos Marcadores Prognósticos para o Câncer de Próstata.}

\begin{tabular}{|c|c|}
\hline \multirow{4}{*}{$\begin{array}{l}\text { Categoria I: } \\
\text { Fatores que provaram seu valor } \\
\text { prognóstico e no manejo do } \\
\text { paciente na prática clínica. }\end{array}$} & $\begin{array}{l}\text { - Níveis séricos, pré-tratamento } \\
\text { de PSA. }\end{array}$ \\
\hline & - Estadiamento patológico TNM. \\
\hline & $\begin{array}{l}\text { - Gradação histológica pela } \\
\text { classificação de Gleason. }\end{array}$ \\
\hline & - Status da margem cirúrgica. \\
\hline \multirow{3}{*}{$\begin{array}{l}\text { Categoria II: } \\
\text { Fatores } \\
\text { estudados } \\
\begin{array}{l}\text { clinicamente, que, no entantonica } \\
\text { necessitam de validação em } \\
\text { estudos } \\
\text { robustos. }\end{array}\end{array}$} & $\begin{array}{l}\text { - Volume tumoral (em } \\
\text { fragmentos de biópsia ou em } \\
\text { peças deprostatectomia). }\end{array}$ \\
\hline & - Sub-tipo histológico. \\
\hline & - Ploi \\
\hline
\end{tabular}




\begin{tabular}{|c|c|}
\hline \multirow{6}{*}{$\begin{array}{l}\text { Categoria III: } \\
\text { Todos os outros fatores ainda } \\
\text { não } \\
\text { Estudados suficientemente para } \\
\text { Demonstrar seu valor prognóstic. }\end{array}$} & - Invasão perineural. \\
\hline & - Densidade de microvasos. \\
\hline & - Derivados do PSA. \\
\hline & - Fatores cariométricos. \\
\hline & $\begin{array}{l}\text { - Marcadores de proliferação } \\
\text { celular. }\end{array}$ \\
\hline & $\begin{array}{l}\text { - Oncogenes e genes de } \\
\text { supressão tumoral. }\end{array}$ \\
\hline
\end{tabular}

Fonte: Bostwick et al. (2000).

\section{ANEXO B - Classificação TNM para o câncer de Próstata (AJCC, 2002).}

\section{Tumor Primário (T)}

- TX: Informação sobre tumor primário não disponível.

- T0: Sem evidência de tumor primário.

- T1: Tumor impalpável e não evidente por métodos de imagem.

- T1a: Tumor encontrado em tecido removido por RTU; 5\% ou menos do tecido ressecado é maligno com grau histológico $\leq 7$.

- T1b: Tumor encontrado em tecido removido por RTU; > 5\% do tecido ressecado é maligno com grau histológico $>7$.

- T1c: Tumor detectado por biópsia prostática devido à elevação no PSA.

- T2: Tumor palpável confiando à próstata.

- T2a: Tumor envolve metade de um lobo ou menos.

- T2b: Tumor envolve mais da metade de um lobo, porém não ambos os lobos.

- T2c: Tumor compromete ambos os lobos. 
- T3: Tumor palpável além da próstata.

- T3a: Extensão extra-capsular unilateral ou bilateral.

- T3b: Tumor invade vesículas seminais.

- T4: Tumor é fixo e invade órgãos adjacentes (que não as vesículas seminais).

- T4a: Tumor invade colo vesical, esfíncter externo e/ou reto.

- T4b: Tumor invade musculatura elevadora do ânus ou é fixo à paredepélvica.

\section{Linfonodos Regionais (N)}

- NX: Informação sobre lifonodos regionais não disponíveis.

- No: Ausência de metástases para lifonodos regionais.

- N1: Metástases para um lifonodo regional único, com $2 \mathrm{~cm}$ ou menos de diâmetro.

- N2: Metástases para um único lifonodo, com diâmetro entre $2 \mathrm{~cm} \mathrm{e}$ $4 \mathrm{~cm}$; ou para linfonodos múltiplos, nenhum destes com mais de 5 $\mathrm{cm}$ de diâmetro.

- N3: Metástases para lifonodos com mais de $5 \mathrm{~cm}$ de diâmetro.

\section{Metástases à Distância (M)}

- MX: Informação sobre metástases à distância não disponível.

- Mo: Ausência de metástases à distância.

- M1: Metástases à distância.

- M1a: envolvimento de linfonodos não regionais.

- M1b: envolvimento de osso.

- M1c: envolvimento de outros sítios à distância. 
ANEXO C - Cadastro dos Pacientes.

Nome

Idade:

Reg.:

Biópsia Pré-Operatória:

Biópsia Pós-Operatória:

Tipo de Tratamento:

PSA Pré-Operatório:

PSA Pós-Operatório: 
Tratamento Complementar:

Nome

Idade: Reg.:

Biópsia Pré-Operatória:

Biópsia Pós-Operatória:

Tipo de Tratamento:

PSA Pré-Operatório:

PSA Pós-Operatório:

Tratamento Complementar:

Nome

Idade: Reg.:

Biópsia Pré-Operatória:

Biópsia Pós-Operatória:

Tipo de Tratamento:

PSA Pré-Operatório:

PSA Pós-Operatório:

Tratamento Complementar:

\section{REFERÊNCIAS}

Aaltomaa S, Lipponen P, Ala-Opas M, Kosma VM. Expression and prognostic value of CD44 standard and variant V3 and V6 isoforms in prostate cancer. Eur. Urol. 2001; 39(2):138-144. 
Alberts B, Johnson A, Lewis, J, Raff M, Roberts K, Walter P. Molecular biology of the cell. 4th ed. New Your: Garland Publishing, 2002.

Albertsen PC, Hanley JA, Penson DF, Fine J. Validation of increasing prostate specific antigen as a predictor of prostate cancer death after treatment of localized prostate cancer with surgery or radiation. $J$ Urol. 2004; 171(6):2221-2225.

Andrade MC. et al. Expressão imuno-histoquímica do CD44V6 e da fibronectina em mucosa oral normal, hyperplasia fibro-epitelial e dysplasia epithelial. RPG, 2003; 10(1):59-69.

Bal N, Wildirim S, Nursal TZ, Bolat F, Kayaselcuk F. Association of ezrin expression in intestinal and diffuse gastric carcinoma with clinicopathological parameters and tumor type. World $J$ of Gastroenterol. 2007 July; 13(27):3726-3729.

Bassett WW, Cooperberg MR, Sadetsky N, et al. Impact of obesity on prostate cancer recurrence after radical prostatectomy: data from CaPSURE. Urology, 2006; 66(5): 1060-1065.

Benson MC, Whang IS, Pantuck A, et al. Prostate specific antigen density: a means of distinguishing benign prostatic hypertrophy and prostate cancer. J Urology, 1992; 147:815-816.

Bertoni F, Bacchini P, Hogendoorn PCW. Chondrosarcoma. In: Fletcher CDM, Unni KK, Mertens F. (editors). Pathology and genetics 
of tumours of soft tissue and bone. Lyon: IARC Press, 2002. (World Health Organization Classification of Tumours, 4).

Bosch P, Stevens JW, Noonan KJ, et al. Expression of CD44 in human neoplastic and normal hyaline cartilage. lowa Orthop. J. 2002; 22:47-54.

Bostwick DG, Grignon DJ, Hammond MEH, et al. Prognostic factors in prostate cancer. College of American Pathologists Consensus Statement 1999. Arch Pathol Lab Med, 2000; 124(7):995-1000.

Brasil. Ministério da Saúde. Instituto Nacional do Câncer. Estimativa de câncer 2008: próstata. Disponível em: <http://www.inca.gov.br/estimativa/2008>. Acesso em: 12 jan. 2008.

Brasil. Ministério da Saúde. Secretaria de Assistência à Saúde. Instituto Nacional de Câncer. Coordenação de Prevenção e Vigilância. Registros Hospitalares de Câncer: rotinas e procedimentos. Rio de Janeiro: INCA; 2000.

Bratt O. Hereditary prostate cancer: clinical aspects. J. Urol. 2002; 168:906-913.

Bretscher A, Reczek D, Berryman M. Ezrin: a protein requiring conformational activation to link microfilaments to the plasma membrane in the assembly of cell surface structures. J Cell Sci, 1997 January; 110(24):3011-3018. 
Bumheida A, Pyrhönen S, Laato M, Collan M. Prognostic factors in prostate cancer. Diagnostic Pathology, 2006; I:4.

Camp RL, Charette LA, Rimm DL Validation of tissue microarray technology in breast carcinoma. Lab. Invest, 2000 Dec; 80(12):19431949.

Carter HB. Pearson JD, Metter EJ, et al. Longitudinal evaluation of prostate-specific antigen levels in men with and without prostate disease. JAMA, 1992; 267:2215-2220.

Catalona WJ, Richie JP, Ahmann FR, et al. Comparison of digital rectal examination and serum prostate specific antigen in the early detection of prostate cancer: results of a multicenter clinical trial of 6,630 men. J Urology, 1994; 151(5):1283-1290.

Cavallaro U, Christofori G. Cell adhesion in tumor invasion and metastasis: loss of the glue is not enough. Biochimica et biofhysica Acta. $2001 ; 1552(1): 39-45$.

Coldman AJ, Phillips N, Pickles TA. Trends un prostate cancer incidence and mortality: an analysis of mortality change by screening intensity. CMAJ, 2003; 168(1):31-35.

Cooper GM, Hausman, RE. The cell: a molecular approach. $3^{\text {rd }}$ ed. Sunderland (MA): Sinauer Associates, 2003. Disponível em: $<$ http://www.ncbi.nlm.nih.gov/entrez/query.fcgi?cmd+Search\&db+boo ks\&doptcmdl+GenBookHL\&term=cooper+mg+adhesion+AND+cooper 
\%5Bbook\%5D+AND+165941\%5Buid\%5D\&rid=cooper.section.2058\#2 059.> Acesso em: 12 jan. 2008.

D'Amico AV, Chen MH, Roehl KA, Catalona WJ. Preoperative PSA velocity and the risk of death from prostate cancer after radical prostatectomy. N Engl J Med. 2004 july; 351(2):125-135.

De Marzo AM, Bradshaw C, Sauvageot J, Epstein JI, Miller GJ. CD44 and CD44v6 downregulation in clinical prostatic carcinoma: relation to Gleason grade and cytoarchitecture. Prostate, 1998; 34(3):162168.

Djavan B, Zlotta AR, Byttebier G, et al. Optimal predictors of prostate cancer on repeat prostate biopsy: a prospective study of 1,051 men. J Urology, 2000, 163:1144-1148.

Eisen MB, Spellman PT, Brown PO, Botstein D. Cluster analysis and display of genome-wide expression patterns. Proc Natl Acad Sci USA, 1998 Dec; 95(25):14863-14868.

Epstein JI, Allsbrook-Jr WC, Amin MB, Egevad LL. Update on the Gleason grading system for prostate cancer. Results of an international consensus conference of urologic pathologists. Adv. Anat. Pathol. 2006; 13:57-59.

Ferrari S, Zanella L, Alberghini M, Palmerini E, Staals E, Bacchini P. Prognostic significance of immunohistochemical expression of ezrin 
in non-metastatic high-grade osteosarcoma. Pediatr Blood Cancer, 2008 April; 50(4):752-756.

Ferreira PRF, Koff WJ. Terapia combinada no câncer de próstata localizado. In: Ferreira PRF. Tratamento combinado em oncologia. Porto Alegre: Artmed, 2007. Cap. 10.

Fox SB, Fawcet J, Jackson DG, et al. Normal human tissues, in addition to some tumors, express multiple different CD44 isoforms. Cancer Res. 1994 Aug; 54:4539-4546.

Frauscher F, Klauser A, Volgger $\mathrm{H}$, et al. Comparison of contrast enhanced color Doppler targeted biopsy with conventional systematic biopsy: impact on prostate cancer detection. J Urology, 2002; $167: 1648-1652$.

Freedland SJ, Csathy GS, Dorey F, Aronson WJ. Percent prostate needle biopsy tissue whit cancer is more predictive of viochemical failure or adverse pathology after radical prostatectomy than prostate specific antigen or Gleason score. J Urology, 2002; 167(2):516-520.

Giltnane JM, Rimm DL. Nature clinical practice. Oncology, 2004, $1(2): 104.111$.

Gion M, Gasparini G. Biomarkers as therapeutic targets: toward personalized treatments in oncology. In: Diamantis EP, et al. (editors). Tumor markers: physiology, pathobiology, technology, and clinical applicatons. Washington DC: AACC Press, 2002. 
Gleason DF. Histologic grading and clinical staging of prostatic carcinoma. In: Tannenbaum M. Urologic Pathology: the prostate. Philadelphia: Lea \& Febiger, 1977.

Gleason DF. Histologic grading of prostate cancer: a perspective. Hum Pathol. 1992; 23:273-279.

Goldstein LA, Zhou DF, Picker IJ, et al. A human lymphocyte homing receptor, the hermes antigen is related to cartilage proteoglycan core and link proteins. Cell, 1989 Mar; 56(6):1063-1072.

Gong Y, Sun X, Huo L, Wiley EL, Rao MS. Expression of cell adhesion molecules CD44s and E-cadherin, and microvessel density in invasive micropapillary carcinoma of the breast. Histopathology, 2005 January; 46(1):24-30(7).

Goodfellow PN, et al. The gene, MIC4 which controls expression of the antigen defined by monoclonal antibody F10.44.2, is on human chomossome 11. Eur J Immunol, 1982; 12(8):659-63.

Goodison S, Urquidi V, Tarin D. CD44 cell adhesion molecules. J Clin Pathol: Molecular Pathology, 1999; 52(4):189-196.

Greenlee RT, Hill-Harmon MB, Murray T, Thun M. Cancer statistics. CA Cancer J Clin. 2001; 51(1):15-36. 
Gronberg H, Damber L, Jonson H. Prostate cancer mortality in northern Sweden, with special reference to tumor grade and patient age. Urology, 2003; 49(3):374-378.

Grubb RL, Kibel AS. Prostate cancer: screening, diagnosis and management in 2007. Mol. Med. 2007 Sep-Oct; 104(5):408-413.

Haas GP, Delongchamps NB, Jones RF, et al. Needle biopsies on autopsy prostates: sensitivity of cancer detection based on true prevalence. J. Natl. Cancer Inst., 2007 October; 99(19):1484-1489.

Hanahan D, Weinberg RA. The hallmarks of cancer. Cell, 2000 January; 100(1):57-70.

Harrison GM, et al. Distribution and expression of CD44 isoforms and erzin during prostate cancer-endothelium interaction. Int J. Oncol, 2002 November; 21(5):935-940.

Hirohashi S. Adhesion system in human cancers. Am J Pathol, 1998; 153(2):333-339.

Hofmann M, Rudy W, Zöller M, et al. CD44 splice variants confer metastatic behavior in rats: homologous sequences are expressed in human tumor cell lines. Cancer Research, 1991 October; 51(19):5292-5297. 
Hudson DL, Speight PM, Watt FM. Altered expression of CD44 isoforms in squamous cell carcinomas and cell lines derived from them. Inter J Cancer, 1996; 66(4):457-463.

Hyoung KP, Choe G, Byun S, Lee H, Lee S, Lee E. Evaluation of concordance of Gleason score between prostatectomy and biopsies thar show more than two different Gleason scores in positive cores. J Urology, 2006; 67:110-114.

Ilmonen S, Vaheri A, Asko-Seljavaara S, Carpen O. Ezrin in primary cutaneous melanoma, Modern Pathology, 2005; 18(4):503-510.

INCA. Instituto Nacional do Câncer. Câncer de próstata. 14 dez. 2005. Disponível em: <http://www.inca.com.br>. Acesso em: 12 jan. 2008.

INCA. Instituto Nacional do Câncer. Câncer de próstata. Disponível em: <http://www.inca.com.br>. Acesso em: 12 jan. 2008.

Jakobsson PA, Eneroth CM, Killander D, Moberger D, Martenson B. Histologic classification and grading of malignancy in carcinoma of the larynx. Acta Radiol. Ther. Phys. Biol. 2004; 12:1-8.

Jalkanen S, Bargatze RF, Herron LR, Butcher EC. A lymphoid cell surface glycoprotein involved in endothelial cell recognition and lymphocyte homing in man. Eur J Immunol, 1986 Oct; 16(10):11951202. 
Jemal A, Siegel R, Ward E, et al. Cancer statistics. CA Cancer J. Clin. 2008; 58(2):71-96.

Jung K, Lein M, Weiss S, Schnorr D, Henke W, Loening S. Soluble CD44 molecules in serum of patients with prostate cancer and benign prostatic hyperplasia. European Journal of Cancer, 1996 April; $32(4): 627-630$.

Jung $\mathrm{K}$, Jung $\mathrm{M}$. Cystatin $\mathrm{C}$ : a promising marker of glomerular filtration rate to replace creatinine. Nephron, 1995; 70(3):370-371.

Kanke M, Fujii Masato, Kameyama Kaori, Kanzaki J, et al. Role of CD44 variant Exon 6 in invasion of head and neck squamous cell carcinoma. Arch. Otolaryngol. Head Neck Surg. 2000; 126(10):12171233.

Kattan MW, Zelefsky MT, Kupelian PA, et al. Pretreatment nomogram that predicts 5-year probability of metastasis following threedimensional conformal radiation therapy for localized prostate cancer. J. Clin. Oncol. 2003; 21(24):4568-4571.

Khanna C, Wan X, Bose S, Cassaday R, et al. The membranecytoskeleton linker ezrin is necessary for osteosarcoma metastasis. Nature Medicine, 2004; 10(2):182-186.

Kim H, Yang XY, Rosada C, et al. CD44 expression in colorectal adenoma is an early event occurring prior to K-ras and p53 gene mutation. Arch Biochem Biophys. 1994 May; 310(2):504-507. 
Kolonel LN, Nomura AMY, Cooney RV. Dietary fat and prostate cancer: current status. J Natl Cancer Inst. 1999; 91(5):414-428.

Kononen J, Bubendorf L, Kallionimeni A, Bärlund M, et al. Tissue microarrays for high-throughput molecular profiling of tumor specimens. Nature Medicine, 1998 July; 4(7):844-847.

Koopman G, Heider KH, Horst E, Adolf GR, et al. Activated human lymphocytes and aggressive non-Hodgkin's lymphomas express a homologue of the rat metastasis-associated variant of CD44. J Exp Med, 1993 April; 177(4):897-904.

Lankes W, Griesmacher A, Grünwald J, Schwarz-Albiez R, Keller R. A heparin-binding protein involved in inhibition of smooth-muscle cell profileration. Biochem J, 1988; 251:831-842.

Li Q, Wu M, Wang H, Xu G, Zhu T, Zhang Y, Liu P, Song A et. al. Ezrin silencing by small hairpin RNA reverses metastatic behaviors of human breast cancer cells. Cancer Lett. 2008 Mar; 261(1):55-63.

Liu AY. Expression of CD44 in prostate cancer cells. Cancer Lett, 1994 Jan: 76(1):63-69.

Mackay CR, Terpe HJ, Stander R, Marston WL, Stark H, Gtinthert. U. Expression and modulation of CD44 variant isoforms in humans. $J$ Cell Biol. 1994; 124:71-82. 
Martin TA, Harrison G, Mansel RE, Jiang WG. The role of the CD44/ezrin complex in cancer metastasis. Crit Rev Oncol Hematol. $2003 ; 46(2): 165-186$.

Merseburger AS, Anastasiadis A, Hennenlotter J, Schilling D, Simon $\mathrm{P}$, et al. Tissue microarrays; applications in urological cancer research. World J Urol, 2006 Nov; 24(5):579-586.

Mohr S, Leikauf GD, KETIH G, Rihn BH. Microarrays as cancers keys: na array of possibilities. J Clin Oncology, 2002 July; 15(14):3165-3175.

Moilanen $J$, Lassus $H$, Leminen A, Vaheri $A$, et al. Ezrin immunoreactivity in relation to survival in serous ovarian carcinoma patients. Gynecol Oncol, 2003 Aug; 90(2):273-281.

Morris SP, Hanlon DO, McLaughlin, McHale T, et al. The prognostic significance of CD44s and CD44V6 expression in stage two breast carcinoma: an immunohistochemical study. Eur J Surg Oncol, 2001, $27(6): 527-531$.

Mucci NR, et al. Neuroendocrine expression in metastatic prostate cancer: evaluation of high throughput tissue microarrays to detect heterogeneous protein expression. Hum Pathol, 2000; 31(4):406414. 
Musial J, Sporny S, Nowicki A. Prognostic significance of E-cadherin and ezrin immunohistochemical expression in prostate cancer. Pol. J. Pathol, 2007, 58(4):235-243.

Naor D, Nedvetzki S, Golan I, Melnik L, Faitelson Y. CD44 in cancer. Crit Rev Clin Lab Sci. 2002 Nov; 38(6):527-579.

Nelson WG, Marzo AM, Isaacs WB. Mechanisms of disease: prostate canser. N. Engl J. Med, 2003, 349:366-381.

Nocito A, Bubendorf NA, Maria TE, et al. Microarrays of bladder cancer tissue are highly representative of proliferation index and histological grade. J Pathol., 2001; 194(3):349-357.

Noordzij MA, Steenbrugge GJ van, Verkaik NS, et al. The prognostic value of CD44 isoforms in prostate cancer patients treated by radical prostatectomy. Clin Cancer Res, 1997 May; 3(5):805-815.

Oesterling JE, Jacobsen SJ, Chute, CG, et al. Serum prostatespecific antigen in a community-based population of healthy men. Establishment of age-specific reference ranges. JAMA, 1993; 270(7):860-864 .

Oliveira DT, Odell EW. Expression of CD44 variant exons by normal oral epithelia. Oral Oncol, 1997, 33(4):260-269.

Pakkanen R, Hedman $\mathrm{K}$, Turunen $\mathrm{O}$, Wahlstrom $\mathrm{T}$, Vaheri A. Microvillus-specific Mr 75,000 plasma membrane protein of human 
choriocarcinoma cells. J. Histochem. Cytochem, 1987; 35(8):809816.

Paradis V, Ferlicot S, Ghannam E, Zeimoura L, Blanchet P, Eschwege P, et al. CD44 is an independent prognostic factor in conventional renal cell carcinomas. J Urol, 1999; 161(6):1984-1987.

Parekh DJ, Ankerst DP, Troyer D, et al. Biomarkers for prostate cancer detection. J Urol, 2007; 178:2252-2259.

Partin AW, Catalona WJ, Southwick PC, Subong EN, Gasior GH, Chan DWAnalysis of percent free prostate-specific antigen (PSA) for prostate cancer detection: influence of total PSA, prostate volume, and age. J Urol, 1996; 48:55-61.

Partin AW, Mangold LA, Lamm DM, et al. Contemporary update of prostate cancer staging nomograms (Partin Tables) for the New Millennium. Urology, 2001; 58(6):843-848.

Perrer SI, et. al. Cancer statistics, 1996. Cancer J. Clin, 1996; 46:527.

Pound CR, Partin AW, Eisenberger MA, et al. Natural history of progression after psa elevation following radical prostatectomy. JAMA, 1999; 281(17):1591-1597. 
Rimm DL, Camp RL, Charette LA, Olsen DA, Provost E. Amplification of tissue by construction of tissue microarrays. Exp. Mol. Pathol, 2001 Juny; 70(3):255-264.

Rudzki Z, Jothy S. CD44 and the adhesion of neoplastic cells. J. Clin. Mol Pathol, 1997; 50(5):57-71.

Scardino PT, Kantoff P, Kozlowski JM, et al. Clinical Practice guidelines in oncology: prostate cancer, version 2. 2005. National Comprehencive Cancer Network (NCCN); 2006.

Schalken JA, Bergh A, Bono A, et al. Molecular prostate cancer pathology: current issues and achievements. Scand J. Urol. Nephrol. Suppl. 2005; 216:82-93.

Schmid HP. Tumour markers in patients on deferred treatment: prostate specific antigen doubling times. Cancer Surv, 1995; 23:157167.

Screaton GR, Bell MV, Bell JI, Jackson DG. The identification of a new alternative exon with highly restricted tissue expression in transcripts encoding the mouse Pgp-1 (CD44) homing receptor. Comparison of all 10 variable exons between mouse, human and rat. J. Biol. Chem, 1993 Juny; 268(17):12.235-12.238.

Sell S. Cancer markers. In: Moossa AR, Schempff SC, Robson MC. (eds.). Comprehensive text-book of oncology. 2nd ed. vol. 1. Baltimore: Williams \& Wilkins, 1991. 
Shen $\mathrm{ZH}$, Chen XY, Chen J. Impact of up-regulating Ezrin expression by Epstein-Barr virus latent membrane protein 1 on metastasis ability of nasopharyngeal carcinoma cells. Ai Zheng, 2008; 27(2):165-169.

Shergill IS, Shergill NK, Arya M, et al. Tissue microarrays: a current medical research tool. Curr. Med. Res. Opin, 2004; 20(5):707-712.

Sommerfeld HJ, Meeker AK, Posadas EM, Coffey DS. Frontiers in prostate cancer: telomeres and chaos. A Cancer J Clinicians, 1995; 75(S7):2027-2035.

Stamenkovic I, Amiot M, Pesandro JM, Seed B, et al. A lymphocyte molecule implicated in lymph node homing is a member of the cartilage link protein family. Cell, 1989; 56:1057-1062.

Stamenkovic I, Aruffo A, Amiot M, et al. The hematopoietic and epithelial forms of CD44 are distinct polypeptides with different adhesion potentials for hyaluronate-bearing cells. EMBO J, 1991; 10:343-348.

Stamey TA, Kalabin JN. Prostate specific antigen in the diagnosis and treatment of adenocarcinoma of the prostate. I. Untreated patients. J. Urol, 1989; 141(5):1070-1075.

Takahashi S, Nagai K, Saito N, Konishi M, Nakagohri T, Gotohdaet $\mathrm{N}$, et al. Multiple resections for hepatic and pulmonary metastases of colorectal carcinoma. Jpn J Clin Oncol, 2007 March; 37(3):186-192. 
Terpe HJ, Stark H, Prehm R Gfinthert U. CD44 variant isoforms are preferentially expressed in basal ephitelial of non-malignant human fetal and adult tissues. Histochemistry, 1994; 101:79-89.

Thompson IM, Pauler DK, Goodman PJ, et al. Prevalence of prostate cancer among men with a prostate-specific antigen leel <or $=4.0 \mathrm{ng}$ per milliliter. N. Engl. J. Med, 2004 May; 350:2239-2246.

Tsukita S, Hieda Y, Tsukita S. A new 82 kD-barbed end capping protein (Radixin) localized in the cell-to-cell adherens junction: purification and characterization. J Cell Biology, 1989, 108:23692382.

Tsukita S, et al. ERM family members as molecular linkers between the cell surface glycoprotein CD44 and actin-based cytoskeletons. $J$ Cell Biol, 1994 July; 126(2):391-401.

Vaheri A, Carpén O, Heiska L, Helander TS, et al. The ezrin protein family: membrane-cytoskeleton interactions and disease associations. Current Opinion in Cell Biology, 1997 Oct; 9(5):659666.

Valdman A, Egevad, L. Heat shock proteins 27, 60 and 70 as prognostic markers of prostate cancer. APMIS, 2008 Oct; 116(10):888-895(8) 
Wang HJ, Zhu JS, Zhang $Q$, Sun $Q$, Guo H. High level of ezrin expression in colorectal cancer tissues is closely related to tumor malignancy. World J Gastroenterol, 2009 April; 15(16):2016-2019.

Wang MC, Valenzuela LA, Murphy GP, Chu TM. Purification of a human prostate specific antigen. Invest. Urol, 1979, 17(2):159-163.

Wayner EA, Carter WG, Piotrowicz RS, Kunicki TJ. The function of multiple extracellular matrix receptors in mediating cell adhesion to extracellular matrix: preparation of monoclonal antibodies to the fibronectin receptor that specifically inhibit cell adhesion to fibronectin and react with platelet glycoprotein Ic-lla. J. Cell Biol, $1988,107(5): 1881-1891$.

Welch HG, Fisher ES, Gottlieb DJ, Barry MJ. Detection of prostate cancer via biopsy in the Medicare-SEER population during the PSA era. J. Natl. Cancer Inst, 2007; 99(18):1395-1400.

Yang N, Stamey TA, Hay AR, Mc Neal JE, Freiha FS, Redwine E. Prostate-specific antigen as a serum marker for adenocarcinoma of the prostate. New Engl. J. Med, 1987; 317(15):909-916.

Yu Y. et al. Expression profiling identifies the cytoeskeletal organizer ezrin and the developmental homeoprotein Six-1 as key metastatic regulators. Nature Medicine, 2004, 10(2):175-181.

Zhou DF, Ding JF, Picker LJ, Bargatze RF, Butcher EC, Goeddel DV. Molecular cloning and expression of Pgp-1: the mouse homolog 
of the human H-CAM (hermes) lymphocyte homing receptor. $J$ Immunol, 1989, 143(10):3390-3395. 